\title{
Carbon dioxide methanation kinetic model on a commercial $\mathrm{Ni} / \mathrm{Al}_{2} \mathrm{O}_{3}$ catalyst
}

\author{
Isabelle Champon ${ }^{1,2,3}$, Alain Bengaouer ${ }^{1}$, Albin Chaise ${ }^{1}$, Sébastien Thomas², Anne-Cécile Roger ${ }^{2}$ \\ 'Université Grenoble Alpes, CEA, LITEN, DTBH, SCTR, LER, 17 Avenue des martyrs, Grenoble F-38054, \\ France \\ ${ }^{2}$ ICPEES-ECPM, UMR 7515, University of Strasbourg, 25 rue Becquerel, F-67087 Strasbourg, France \\ ${ }^{3}$ French Environment and Energy Management Agency, 20 avenue du Grésillé, BP 90406, F-49004, \\ Angers Cedex 01, France
}

Corresponding author: alain.bengaouer@cea.fr (Alain Bengaouer)

\begin{abstract}
Intrinsic kinetic characterization of the carbon dioxide methanation was determined over a commercial $14-17 \mathrm{wt} . \% \mathrm{Ni} / \mathrm{Al}_{2} \mathrm{O}_{3}$ between $623 \mathrm{~K}$ and $723 \mathrm{~K}$ at atmospheric pressure in the absence of heat and mass transfer limitations. Following a Hougen-Watson formalism, both direct path $\left(\mathrm{CO}_{2}\right.$ methanation rate equation) and indirect path (Reverse Water Gas Shift rate equation + $\mathrm{CO}$ methanation rate equation) were described. As a first step, kinetic tests were performed operating in differential mode to evaluate the reaction rate dependence on reactants and products partial pressure at different temperatures in order to select the form of each reaction rate equation. Kinetic models available in the literature were evaluated and compared with the experimental results and model adaptations were proposed to identify the kinetic laws that fit the best the experimental values. Kinetic and adsorption parameters were calculated from these laws. Then, the identified parameters were adjusted simultaneously on experimental tests from $5 \%$ to $75 \% \mathrm{CO}_{2}$ conversion using an isothermal plug-flow reactor. The three reaction rates and their reverse reactions were identified in order to minimize the error on $\mathrm{CO}_{2}$ conversion and $\mathrm{CH}_{4}$ and $\mathrm{CO}$ selectivities at $623 \mathrm{~K}, 673 \mathrm{~K}$ and $723 \mathrm{~K}$. The final identified kinetic model was able to reflect the kinetics from differential conversion to thermodynamic equilibrium with an accuracy of $20 \%$ on the $\mathrm{CH}_{4}$ formation rate for the three temperatures.
\end{abstract}

\section{Keywords: carbon dioxide, methanation, Power-to-Gas, intrinsic kinetics, $\mathrm{Ni} / \mathrm{Al}_{2} \mathrm{O}_{3}$ catalyst}

\section{Introduction}

The $\mathrm{CO}_{2}$ methanation reaction is of great interest today in the case of Power-to-Gas technologies [17]. Actually this reaction, also called the Sabatier reaction [8], produces Substitute Natural Gas (SNG) and enables the $\mathrm{CO}_{2}$ valorization (from biomass or industrial flux gases for instance) in order to reduce the greenhouse gas emissions. Moreover, Power-to-Gas is known as one of the solutions to store the excess and intermittent electricity production from renewable energy [4]. Hydrogen is first synthetized by water electrolysis, and then combined with carbon dioxide to produce methane and water. Thereafter, methane can be injected in the gas grid and is more easily stored than hydrogen. It can be transported via the gas grid, and be used in a great variety of end-use applications (heat, mobility, etc.) [4].

The $\mathrm{CO}_{2}$ hydrogenation into $\mathrm{CH}_{4}$ (reaction (1)) is balanced, highly exothermic, favored at low temperatures and high pressures.

As reactions in gas phase are extremely slow at moderate temperatures and pressures, a catalyst is needed to obtain an acceptable reaction rate and methane selectivity [5]. Supported catalysts are widely used to perform $\mathrm{CO}_{2}$ methanation. Usually, they are composed of a metallic active phase $(\mathrm{Ni}, \mathrm{Ru}, \mathrm{Rh}$, $\mathrm{Co}$ ), dispersed on an oxide support $\left(\mathrm{Al}_{2} \mathrm{O}_{3}, \mathrm{CeO}_{2}, \mathrm{SiO}_{2}\right.$, etc.). Nickel based catalysts supported on alumina are the most largely employed because of their high performance/cost ratio [3].

The $\mathrm{CO}_{2}$ methanation can also be a combination of Reverse Water Gas Shift (RWGS) and CO methanation (balanced reactions (2) and (3)) [9]. 


$$
\begin{aligned}
\mathrm{CO}_{2}+4 \mathrm{H}_{2} & \rightleftharpoons \mathrm{CH}_{4}+2 \mathrm{H}_{2} \mathrm{O} & \Delta_{r} H_{298 \mathrm{~K}}^{0}=-165 \mathrm{~kJ} \cdot \mathrm{mol}^{-1} \\
\mathrm{CO}_{2}+\mathrm{H}_{2} & \rightleftharpoons \mathrm{CO}+\mathrm{H}_{2} \mathrm{O} & \Delta_{r} \mathrm{H}_{298 \mathrm{~K}}^{0}=41 \mathrm{~kJ}^{\mathrm{mol}} \mathrm{mol}^{-1} \\
\mathrm{CO}+3 \mathrm{H}_{2} & \rightleftharpoons \mathrm{CH}_{4}+\mathrm{H}_{2} \mathrm{O} & \Delta_{r} \mathrm{H}_{298 \mathrm{~K}}^{0}=-206 \mathrm{~kJ} . \mathrm{mol}^{-1}
\end{aligned}
$$

Several authors have studied the $\mathrm{CO}$ and $\mathrm{CO}_{2}$ methanation kinetics. Some studies use a simple power rate law [10-12]. However, more rigorous models result from reaction mechanism considerations and follow the Hougen Watson formalism. A recent review introduced exhaustively the $\mathrm{CO}$ and $\mathrm{CO}_{2}$ methanation kinetics [6].

$\mathrm{Xu}$ and Froment [13] proposed three reaction rates on a $15.2 \mathrm{wt} . \% \mathrm{Ni} / \mathrm{MgAl}_{2} \mathrm{O}_{4}$ catalyst, derived from methane steam reforming, $\mathrm{CO}_{2}$ methanation and reverse water gas shift experiments. Experimentally, the fixed-bed reactor was operated in integral mode (reaction rates cannot be considered as constant along the catalyst bed) with $400.0 \mathrm{mg}$ of commercial catalyst diluted with $\alpha$-alumina. The data used for the kinetic study were recorded after $70 \mathrm{~h}$ on stream to stabilize its activity. The conditions of the experiments were 573 to $673 \mathrm{~K}, 300$ to $1000 \mathrm{kPa}$ and 6 to $30 \mathrm{ml}$ (STP) $\mathrm{min}^{-1}$. They employed a Marquardt routine to estimate the kinetic parameters by minimization of the sum of weighted residual squares of the conversions, the latter being calculated by the fourth-order Runge-Kutta routine. Finally, they identified 14 parameters: activation energies and pre-exponential factors of the 3 kinetic constants corresponding to the three reactions (Eqs (1), (2), and (3)), following an Arrhenius law and heat of adsorption and preexponential factors of 4 adsorption constants, as Van't Hoff-type. However, they obtained a negative heat of adsorption for water, which has no physical meaning.

Ducamp et al. [14] proposed a kinetic model based on the $\mathrm{Xu}$ and Froment kinetic formalism and adjusted on 15.0-26.0 mg of a commercial $17 \mathrm{wt} . \% \mathrm{Ni} / \mathrm{Al}_{2} \mathrm{O}_{3}$ catalyst diluted in $\mathrm{SiC}$ and operating in integral mode. The conditions of the experiments were 553 to $673 \mathrm{~K}, 100$ to $1000 \mathrm{kPa}$ and $120-125 \mathrm{ml}$ (STP) $\mathrm{min}^{-1}$ in stoichiometric conditions for the $\mathrm{CO}_{2}$ methanation and in hydrogen excess for the $\mathrm{CO}$ methanation - in order to slow down the catalyst deactivation. Only the three kinetic constants and the $\mathrm{CO}$ adsorption constant were identified. All other constants were unchanged, even if the two catalysts were different and if the water heat of adsorption was negative.

Weatherbee and Bartholomew [15] measured the rate of $\mathrm{CO}_{2}$ hydrogenation on $300.0 \mathrm{mg}$ of a $3 \mathrm{wt} . \%$ $\mathrm{Ni} / \mathrm{SiO}_{2}$ catalyst, between 500 and $600 \mathrm{~K}, 140$ to $175 \mathrm{kPa}$, and 500 to $1500 \mathrm{ml}(\mathrm{STP}) \mathrm{min}^{-1}$. The $\mathrm{CO}_{2}$ conversion was limited to $10 \%$, so the reactor was operated in differential mode. $\mathrm{H}_{2}$ and $\mathrm{CO}_{2}$ partial pressure rate dependence were established. As $\mathrm{CO}$ was produced by the reaction (Eq (2)), some tests were performed with $\mathrm{CO}$ at the inlet of the reactor. The $\mathrm{CO}_{2}$ methanation rate decreased in the presence of $\mathrm{CO}$. A kinetic law for the $\mathrm{CO}_{2}$ methanation reaction was proposed, assuming the formation of adsorbed $\mathrm{CO}$ which could further dissociate or desorb. Nevertheless, they neglected the $\mathrm{CO}$ methanation path which could also form $\mathrm{CH}_{4}$.

Recently, Koschany et al. [16] studied the $\mathrm{CO}_{2}$ methanation kinetic in differential mode considering only the direct path (Eq (1)), neglecting the reverse water gas shift reaction because the CO content in the product gas was below $1000 \mathrm{ppm}$. They prepared a co-precipitated $\mathrm{NiAl}(\mathrm{O}) \times$ catalyst. A mass of 25.0 to $75.0 \mathrm{mg}$ of catalyst (30-90 wt.\% Ni) diluted in $\mathrm{SiC}$ was stabilized for $300 \mathrm{~h}$ on stream. Temperature was varied between 453 and $523 \mathrm{~K}$. Pressure was limited to $2000 \mathrm{kPa}$ and flow rates were set from 45 to $75 \mathrm{ml}$ (STP) $\mathrm{min}^{-1}$.

Miguel et al. [17] determined the intrinsic kinetics of $\mathrm{CO}_{2}$ methanation over a commercial calcium aluminate catalyst (20-25 wt.\% NiO). Temperature varied between 523 and $623 \mathrm{~K}$ at atmospheric pressure. 12.0 to $40.0 \mathrm{mg}$ of catalyst was employed for a total feed flow rates of $30-100 \mathrm{ml}$ (STP) $\mathrm{min}^{-1}$.

At an industrial or pilot scale, different reactor types are used (fluidized bed reactors, adiabatic or cooled fixed-bed reactors, micro-reactors, metallic-foam reactors, structured coated reactors or millistructured fixed-bed reactors-exchangers) $[6,18,19,14,20]$.

The purpose of this study is to develop a new kinetic model accounting for the direct (Eq (1)) and indirect paths (Eqs (2) + (3)) of the $\mathrm{CO}_{2}$ methanation reaction with a 14-17 wt.\% Ni/Al $\mathrm{Al}_{2} \mathrm{O}_{3}$ commercial catalyst from $623 \mathrm{~K}$ until $723 \mathrm{~K}$ at atmospheric pressure. The temperature range of this study is explained by the fact that the proposed kinetic model is intended to be used to describe the behavior of a milli- 
structured fixed-bed reactor-exchanger channel. The temperatures of interest are therefore around 573 $\mathrm{K}$.

\section{Experimental Study}

\subsection{Equipment and materials}

Experimental kinetic tests were performed at atmospheric pressure, between $623 \mathrm{~K}$ and $723 \mathrm{~K}$ on a $14-17 \mathrm{wt} . \% \mathrm{Ni} / \mathrm{Al}_{2} \mathrm{O}_{3}$ commercial catalyst. Catalyst (mass between $1.5 \mathrm{mg}$ and $10.0 \mathrm{mg}$ ) was diluted in $\mathrm{SiC}(4<\Psi<32)$ in the grain size range $125-250 \mu \mathrm{m}$.

Kinetic measurements setup was divided in three parts: gas alimentation and mixing, reaction zone and analysis section. Mass flow controllers commanded the gas feeding of the six lines $\left(\mathrm{H}_{2}, \mathrm{~N}_{2}-\right.$ internal standard for the $\mathrm{GC}$ analysis, $\mathrm{CO}_{2}, \mathrm{CH}_{4}, \mathrm{CO}$, and $\mathrm{Ar}$ ). The pure gases were mixed together before the reaction zone and heated up using heating tapes. Liquid water was injected into a vaporization chamber by a micro-pump (GILSON - Model 321322350), and steam mingled with the gas mixture. All the tubes were heated after the vaporization chamber to avoid water condensation. A tubular furnace, constituting the reaction zone, heated the glass reactor until $773 \mathrm{~K}$. The reactor was $30 \mathrm{~cm}$ long and 3.0 $\mathrm{mm}$ inner diameter. The catalyst bed was fixed with quartz wool and located inside the isothermal zone of the furnace. A thermocouple measured the temperature at the end of the catalyst bed. After the reaction zone, a cold trap condensed the water. The dry gas mixture entered the analysis zone composed by a micro gas chromatography (INFICON 3000 MICRO GC) equipped with two columns. The MS5A module was used to separate $\mathrm{H}_{2}, \mathrm{~N}_{2}, \mathrm{CH}_{4}$ and $\mathrm{CO}$ and the PPQ module to separate $\mathrm{CH}_{4}, \mathrm{CO}_{2}$ and $\mathrm{C}_{2} \mathrm{H}_{6}$ (if present). Both were equipped with TCD detectors. For one condition (temperature/flow rate), the catalyst was hold until stabilization of the conversion (45 minutes to 60 minutes) and an average of the 15 last minutes ( $4-5$ points) was taken as the mean value of conversion.

\subsection{Pretreatment of the catalyst}

A step of catalyst activation under hydrogen was needed to reduce $\mathrm{NiO}$ into $\mathrm{Ni}^{\circ}(\mathrm{Eq}(4))$ :

$$
\mathrm{NiO}+\mathrm{H}_{2} \rightarrow \mathrm{Ni}^{\circ}+\mathrm{H}_{2} \mathrm{O}
$$

A temperature-programed reduction (TPR) was realized to establish the reduction conditions. TPR was conducted with $10 \% \mathrm{H}_{2}$ in $\mathrm{Ar}$ with a total flow of $50 \mathrm{ml}(\mathrm{STP}) \mathrm{min}^{-1}$; heating rate $10 \mathrm{~K} \mathrm{~min}^{-1}-1273 \mathrm{~K}$, holding for $60 \mathrm{~min}$ (see Figure 1). The first reduction zone, below $673 \mathrm{~K}$, was associated with the reduction of bulk $\mathrm{NiO}$ and the second one, above $673 \mathrm{~K}$, with $\mathrm{NiO}$ in strong interaction with $\mathrm{NiAl}_{2} \mathrm{O}_{4}$. Following the industrial recommendations and in order to obtain a catalyst as stable as possible, only the bulk $\mathrm{NiO}$ reduction was sought by in situ reduction. Consequently, the reactor was heated up under a mixture $50 \%$ $\mathrm{H}_{2}$ in $\mathrm{N}_{2}$, with a total flow of $16 \mathrm{ml}(\mathrm{STP}) \mathrm{min}^{-1}$ at $5 \mathrm{~K} \mathrm{~min}^{-1}$ until $673 \mathrm{~K}$ and was kept at $673 \mathrm{~K}$ for $1 \mathrm{~h}$.

Before starting the kinetic tests, the catalyst was stabilized by thermal cycling under reactive flow $\left(\mathrm{H}_{2} / \mathrm{CO}_{2} / \mathrm{N}_{2}: 74 / 17 / 9\right): 673 \mathrm{~K}(1 \mathrm{~h}), 723 \mathrm{~K}(1 \mathrm{~h})$ and $748 \mathrm{~K}$ during one night $(15 \mathrm{~h})$. The repetition of the activity tests at $623 \mathrm{~K}(1 \mathrm{~h})-673 \mathrm{~K}(1 \mathrm{~h})-723 \mathrm{~K}(1 \mathrm{~h})$ showed a stable catalytic activity.

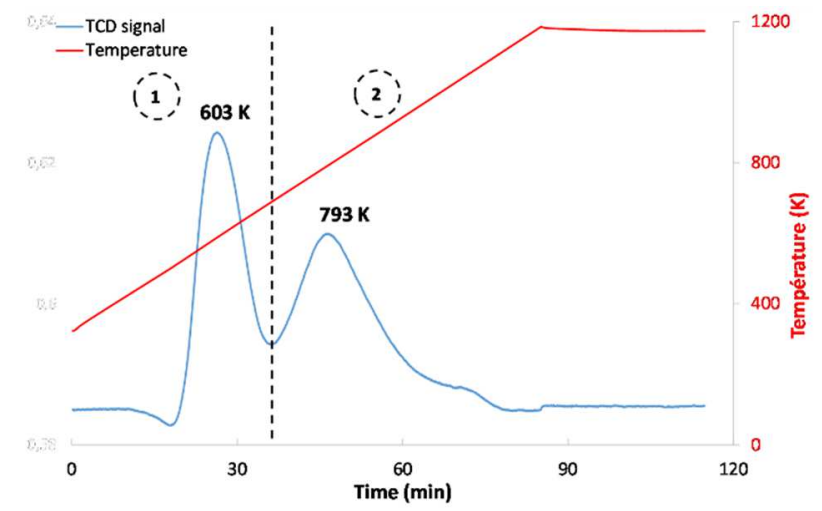

Figure 1 : Reduction profile of the commercial catalyst $\mathrm{Ni} / \mathrm{Al}_{2} \mathrm{O}_{3}$

\subsection{Diffusional limitations}

Catalyst was diluted in $\mathrm{SiC}$ because of its thermal properties but also to increase the height of catalytic bed to obtain a plug flow reactor behavior. The plug flow assumption inside the reactor was validated 
theoretically by the absence of axial dispersion $\left(h_{\text {bed }} / d_{p}>50[21,22]\right)$ and radial dispersion $\left(d_{t} / d_{p}>8\right.$ [23]). The relative pressure drop over the catalyst bed was less than $20 \%$ and can be neglected [24].

To ensure the determination of the intrinsic chemical kinetics, both external and internal diffusional limitations were checked at $723 \mathrm{~K}$ (maximal temperature of the study). The results are presented in Figure 2.

For the verification of the absence of external transport resistances, the feed flow rate and the catalyst mass were varied, keeping the same ratio flow rate/catalyst mass (same GHSV). The $\mathrm{CO}_{2}$ conversion obtained with catalyst mass $\mathrm{m}=1.5 \mathrm{mg}$ and flow rate $\mathrm{Q}=27.5 \mathrm{ml}$ (STP) $\mathrm{min}^{-1}$ was very close to the one obtained for mass $2 \mathrm{~m}=3.0 \mathrm{mg}$ and flow rate $2 \mathrm{Q}=55.0 \mathrm{ml}(\mathrm{STP}) \mathrm{min}^{-1}$ at $673 \mathrm{~K}$ and $723 \mathrm{~K}$ and far from thermodynamic limitations (see Figure 2 (a) for a GHSV $=9.6010^{5} \mathrm{~h}^{-1}$ ). Similarly, the $\mathrm{CO}_{2}$ conversion obtained with catalyst mass $\mathrm{m}=1.5 \mathrm{mg}$ and flow rate $\mathrm{Q}=41.3 \mathrm{ml}$ (STP) $\mathrm{min}^{-1}$ was very close to the one obtained for mass $2 \mathrm{~m}=3.0 \mathrm{mg}$ and flow rate $2 \mathrm{Q}=82.5 \mathrm{ml}$ (STP) $\mathrm{min}^{-1}$ at $723 \mathrm{~K}$ and far from thermodynamic limitations (see Figure 2 (a) for a GHSV $=1.4410^{6} \mathrm{~h}^{-1}$ )

The external diffusion is promoted by the gas velocity increase, however, as similar conversions were obtained in both cases, the external diffusion can therefore be considered as not limiting for total flow rates over $27.5 \mathrm{ml}$ (STP) $\mathrm{min}^{-1}$.

For the internal diffusional limitations, the size of the catalyst particles was varied between $63 \mu \mathrm{m}$ and $400 \mu \mathrm{m}$ in several fragments by crushing and sieving: 63-125 $\mu \mathrm{m}, 125-250 \mu \mathrm{m}, 250-315 \mu \mathrm{m}, 315-400 \mu \mathrm{m}$. The internal limitations are well seen from $\mathrm{CO}_{2}$ conversion obtained for 315-400 $\mu \mathrm{m}$ to $63-125 \mu \mathrm{m}$ fractions (Figure 2 (b)). However, the relative pressure drop over the catalyst bed with 63-125 $\mu \mathrm{m}$ fraction was not negligible. Moreover, the $\mathrm{CO}_{2}$ conversion relative gap between 125-250 $\mu \mathrm{m}$ fraction and 63-125 $\mu \mathrm{m}$ fraction is less than $7 \%$. Hence, it was assumed that the internal diffusion was not significantly limiting for the grain size $125-250 \mu \mathrm{m}$, even if the transport resistance inside the grain is not zero. Thus, the kinetic study is performed with particles size between 125 and $250 \mu \mathrm{m}$.

Also, the theoretical heat and mass transfer limitations verifications were calculated according to the Mears-Anderson-Weisz-Prater criteria (see appendix A for details) to verify that the kinetic measurements were not affected by the mass and thermal diffusion limitations.

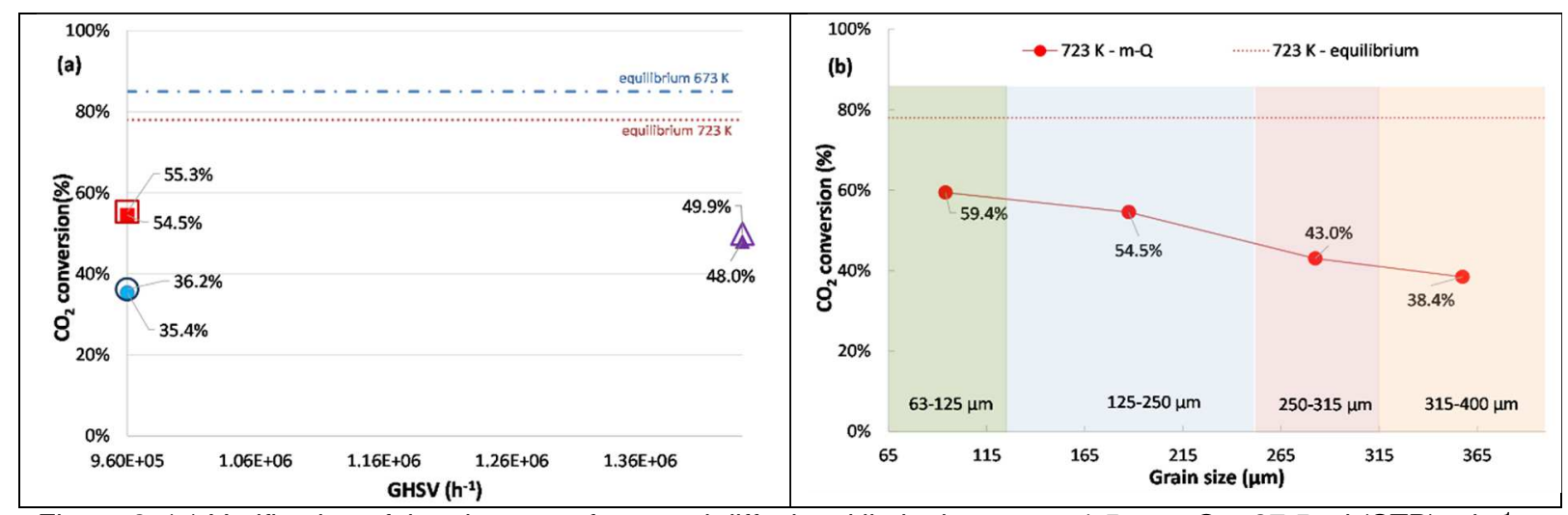

Figure 2: (a) Verification of the absence of external diffusional limitations ; $\mathrm{m}=1.5 \mathrm{mg} ; \mathrm{Q}=27.5 \mathrm{ml}(\mathrm{STP}) \mathrm{min}^{-1} \bullet$ at $673 \mathrm{~K}$ at $723 \mathrm{~K}$ and $\boldsymbol{\Delta} \mathrm{m}=1.5 \mathrm{mg}$ and $\mathrm{Q}=41.3(\mathrm{STP}) \mathrm{min}^{-1}$ at $723 \mathrm{~K}$ compared respectively to $2 \mathrm{~m}$ and $2 \mathrm{Q}$ $(\circ, \square, \Delta)(b)$ verification of the absence of internal diffusional limitations at $723 \mathrm{~K} ; \mathrm{m}=1.5 \mathrm{mg} ; \mathrm{Q}=27.5 \mathrm{ml}$ (STP) min $^{-1}$

\subsection{Kinetic measurements}

Kinetic experiments aim at determining the reaction rate of the three reactions (Eqs (1), (2) and (3)) in a two-step procedure. First, the forms of the reaction rates are identified by low-conversion experiments with a rough estimation of their numerical parameters, which are then adjusted at higher conversion rate.

The aim of the tests at low conversion is to establish the partial pressure rate dependence of each component on each reaction, at different temperatures. To do so, the inlet partial pressure of one compound was varied while keeping the others constant. This was performed with the use of an argon flow. A maximum conversion of $20 \%$ was tolerated to assume constant reaction rate along the reactor axis. Indeed, on the basis of low conversion, the reactants partial pressure alongside the catalyst bed was assumed to be constant, and equal to the inlet values. Moreover, the reverse reactions were neglected 
(far from thermodynamic limitations), and the effects of the products formed by the reactions $\left(\mathrm{CO}, \mathrm{H}_{2} \mathrm{O}\right.$, $\mathrm{CH}_{4}$ ) were expected to be weak enough to be neglected (no chain reaction or products inhibition).

According to these assumptions, with a $\mathrm{H}_{2} / \mathrm{CO}_{2}$ flow at the reactor inlet, the $\mathrm{CH}_{4}$ formation rate is equal to the $\mathrm{CO}_{2}$ methanation reaction rate, and the $\mathrm{CO}$ formation rate equals the RWGS reaction rate:

$$
\begin{gathered}
r_{\text {meth } \mathrm{CO}_{2}}=r_{\mathrm{CH}_{4}} \\
r_{R W G S}=r_{\mathrm{CO}}
\end{gathered}
$$

With a $\mathrm{H}_{2} / \mathrm{CO}$ flow at the inlet, the $\mathrm{CH}_{4}$ formation rate is associated to the $\mathrm{CO}$ methanation reaction rate:

$$
r_{\text {meth } C O}=r_{\mathrm{CH}_{4}}
$$

In order to study the influence of the products on the reaction rates, some tests were performed with a product of the possible reactions $\left(\mathrm{CH}_{4}\right.$ or $\left.\mathrm{H}_{2} \mathrm{O}\right)$ at the inlet of the reactor. To reduce the partial pressure variation alongside the catalytic bed and thus to be able to consider inlet partial pressure in the calculation, relatively high partial pressures of products were used at the reactor inlet in order to obtain $F_{\text {products }}{ }^{\text {inlet }} \gg$ $F_{\text {products }}$ formed.

Existing models from the literature were evaluated against the experimental results. They were adapted to better fit the experimental data. Finally, a first estimation of the kinetic and adsorption parameters of the three reactions were determined.

In the second set of experiments, the parameters were adjusted in order to fit experimental data at higher conversion rate. Experimentally, catalyst mass and total reactive flow rate were varied in order to reproduce the conversion rate range of an isothermal plug flow reactor. GHSV between $2.8810^{6} \mathrm{~h}^{-1}$ and $1.4610^{5} \mathrm{~h}^{-1}$ were tested at $623 \mathrm{~K}, 673 \mathrm{~K}$ and $723 \mathrm{~K}$ according to the following conditions $\left(\mathrm{H}_{2} / \mathrm{CO}_{2}=4\right.$ and $\mathrm{N}_{2}=10 \%$ of the reactive flow rate):

- A batch of $1.5 \mathrm{mg}$ of catalyst diluted in $\mathrm{SiC}(\Psi=32)$ and a flow rate of $82.5 \mathrm{ml}(\mathrm{STP}) \mathrm{min}^{-1}$

- A batch of $2.0 \mathrm{mg}$ of catalyst diluted in $\mathrm{SiC}(\Psi=24)$ and three flow rates (82.5-55.0-27.5 ml (STP) $\min ^{-1}$ )

- A batch of $10.0 \mathrm{mg}$ of catalyst diluted in $\mathrm{SiC}(\Psi=4)$ and three flow rates (82.5-55.0$\left.27.5 \mathrm{ml}(\mathrm{STP}) \mathrm{min}^{-1}\right)$.

Numerically, an isothermal plug flow was modeled by 100 CSTR in series with the same mass of catalyst. The kinetic laws and their roughly estimated numerical parameters were employed to evaluate the partial flow rate alongside the catalytic bed with the three reactions occurring in parallel, according to the composition, flow rate and pressure at the inlet of the reactor and the conditions of temperature and catalyst mass. A linear pressure drop was assumed between the reactor inlet (around $130 \mathrm{kPa}$ ) and the atmospheric pressure at the outlet. The equilibrium constants of the three reactions were calculated according to the Gibbs equation. The roughly estimated parameters of the kinetic model were then adjusted simultaneously to minimize the error on $\mathrm{CO}_{2}$ conversion and $\mathrm{CH}_{4}$ and $\mathrm{CO}$ selectivities at $623 \mathrm{~K}$, $673 \mathrm{~K}$ and $723 \mathrm{~K}$.

\section{Results}

\section{1. $\underline{\mathrm{CO}_{2}}$ methanation}

The $\mathrm{CO}_{2}$ methanation rate dependence on reactants and products partial pressure has been established at different temperatures with $1.5 \mathrm{mg}$ of Ni/Al${ }_{2} \mathrm{O}_{3}$ catalyst diluted in $\mathrm{SiC}(\Psi=32)$. The rate of $\mathrm{CH}_{4}$ formation is highly dependent on the $\mathrm{H}_{2}$ concentration (Figure 3 (a) at $22 \mathrm{kPa} \mathrm{CO}_{2}$ partial pressure) whereas it is weakly dependent on the $\mathrm{CO}_{2}$ partial pressure (Figure $3(\mathrm{~b})$ at $55 \mathrm{kPa} \mathrm{H}_{2}$ partial pressure). No significant influence of $\mathrm{CH}_{4}$ partial pressure on $\mathrm{CH}_{4}$ formation rate is detected (Figure 3 (c) at $55 \mathrm{kPa}$ $\mathrm{H}_{2}$ partial pressure and $22 \mathrm{kPa} \mathrm{CO}$ partial pressure) whereas an inhibition by water pressure is observed in Figure $3(d)$.

\section{2. $\underline{\mathrm{RWGS}}$}

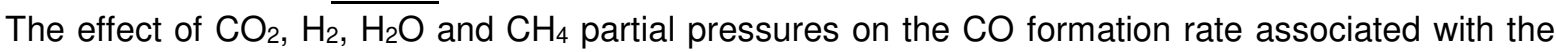
RWGS reaction was studied on $1.5 \mathrm{mg} \mathrm{Ni} / \mathrm{Al}_{2} \mathrm{O}_{3}$ catalyst diluted in $\mathrm{SiC}(\Psi=32)$. No dependence on the $\mathrm{H}_{2}$ concentration is visible (Figure 4 (a) at $22 \mathrm{kPa} \mathrm{CO}_{2}$ partial pressure) whereas the rate of $\mathrm{CO}$ formation is highly dependent on the $\mathrm{CO}_{2}$ concentration (Figure 4 (b) at $55 \mathrm{kPa} \mathrm{H}$ partial pressure). No influence 
of $\mathrm{CH}_{4}$ partial pressure and an inhibition by water pressure (Figure 4 (c) and (d)) are observed at $55 \mathrm{kPa}$ $\mathrm{H}_{2}$ partial pressure and $22 \mathrm{kPa} \mathrm{CO} 2$ partial pressure.

The effect of $\mathrm{CO}$ partial pressure has been investigated on the $\mathrm{CO}_{2}$ formation rate associated with the WGS reaction (reverse reaction of $\mathrm{Eq}(2)$ ), i.e. with a flow of $\mathrm{CO} / \mathrm{H}_{2} \mathrm{O}$ at the entry of the reactor to avoid the competition with methanation reactions. $\mathrm{CO}_{2}$ formation rate is moderately dependent on $\mathrm{CO}$ partial pressure (Figure 5 at $20 \mathrm{kPa} \mathrm{H}_{2} \mathrm{O}$ partial pressure).

\subsection{CO methanation}

The $\mathrm{CO}$ methanation rate dependence on reactants partial pressure was determined at $623 \mathrm{~K}, 673 \mathrm{~K}$ and $723 \mathrm{~K}$. A quasi linear dependence on the $\mathrm{H}_{2}$ partial pressure (Figure 6 (a) at $25 \mathrm{kPa}$ CO partial pressure) was observed whereas the dependence on $\mathrm{CO}$ is much weaker (Figure 6 (b) at $40 \mathrm{kPa} \mathrm{H}$ partial pressure).
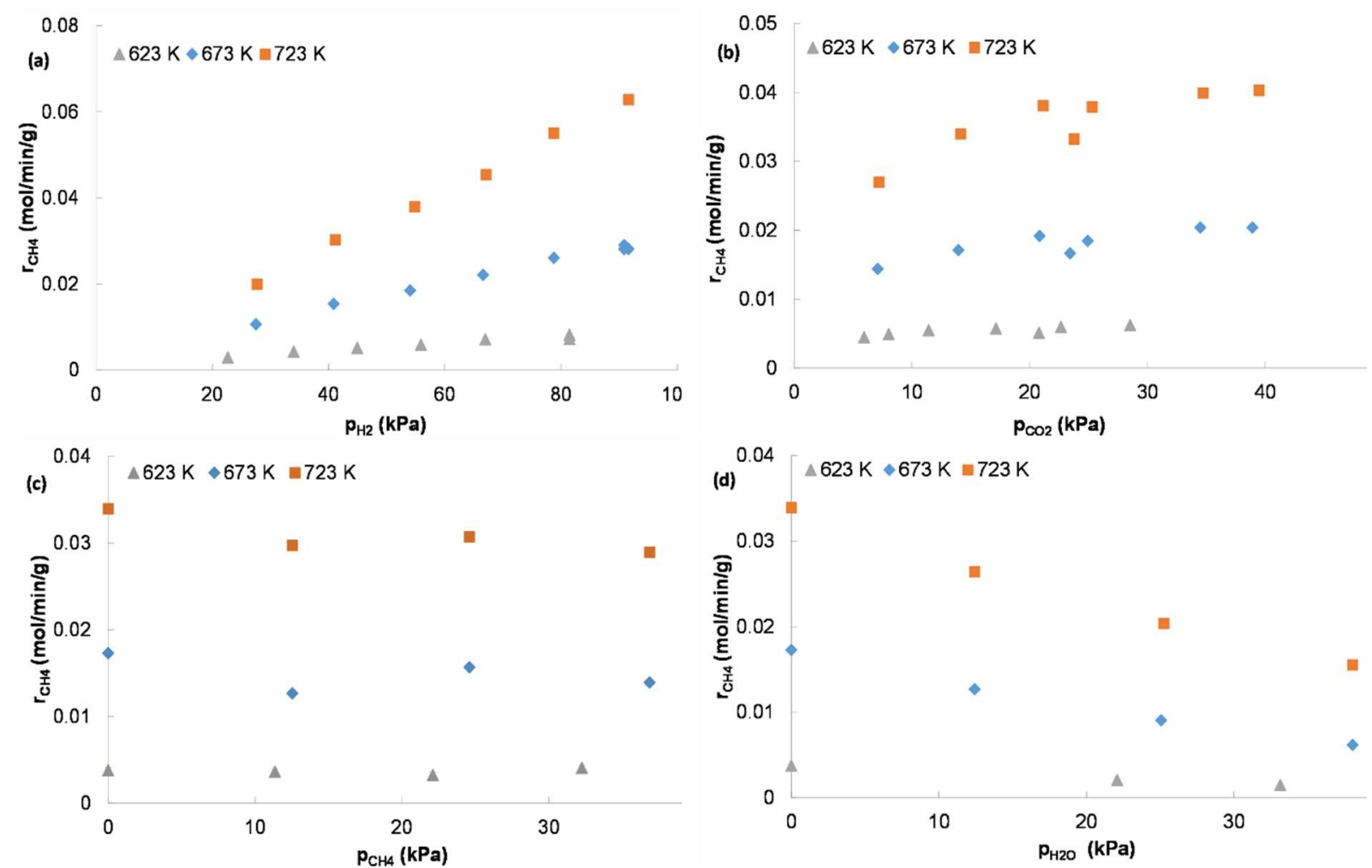

Figure 3 : Effect of partial pressure on $\mathrm{CO}_{2}$ methanation on $1.5 \mathrm{mg} \mathrm{Ni} / \mathrm{Al}_{2} \mathrm{O}_{3}$ catalyst diluted in $\mathrm{SiC}, 115 \mathrm{kPa}$ total pressure and $1.0610^{6} \mathrm{~h}^{-1}$ at $623 \mathrm{~K}-130 \mathrm{kPa}$ total pressure and $3.1610^{6} \mathrm{~h}^{-1}$ at $673 \mathrm{~K}$ and $723 \mathrm{~K}:$ (a) $\mathrm{H}_{2}$ at $22 \mathrm{kPa}$ $\mathrm{CO}_{2}$ partial pressure; (b) $\mathrm{CO}_{2}$ at $55 \mathrm{kPa} \mathrm{H}_{2}$ partial pressure; (c) $\mathrm{CH}_{4}$ and (d) $\mathrm{H}_{2} \mathrm{O}$ at $55 \mathrm{kPa} \mathrm{H}$ partial pressure and $22 \mathrm{kPa} \mathrm{CO} 2$ partial pressure
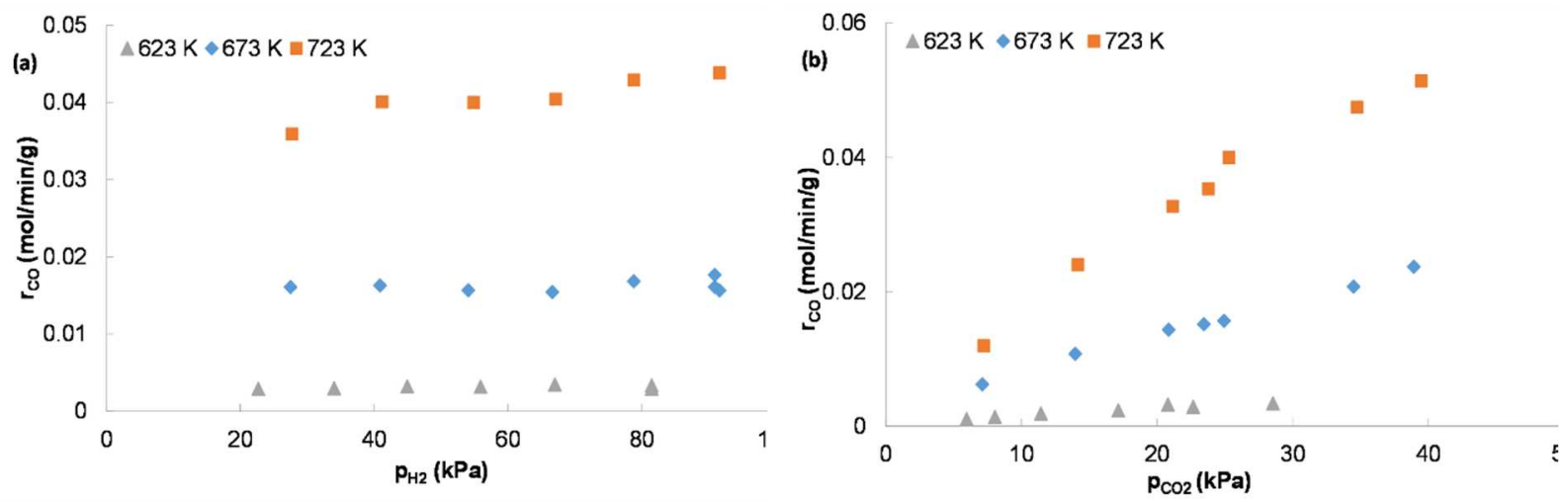


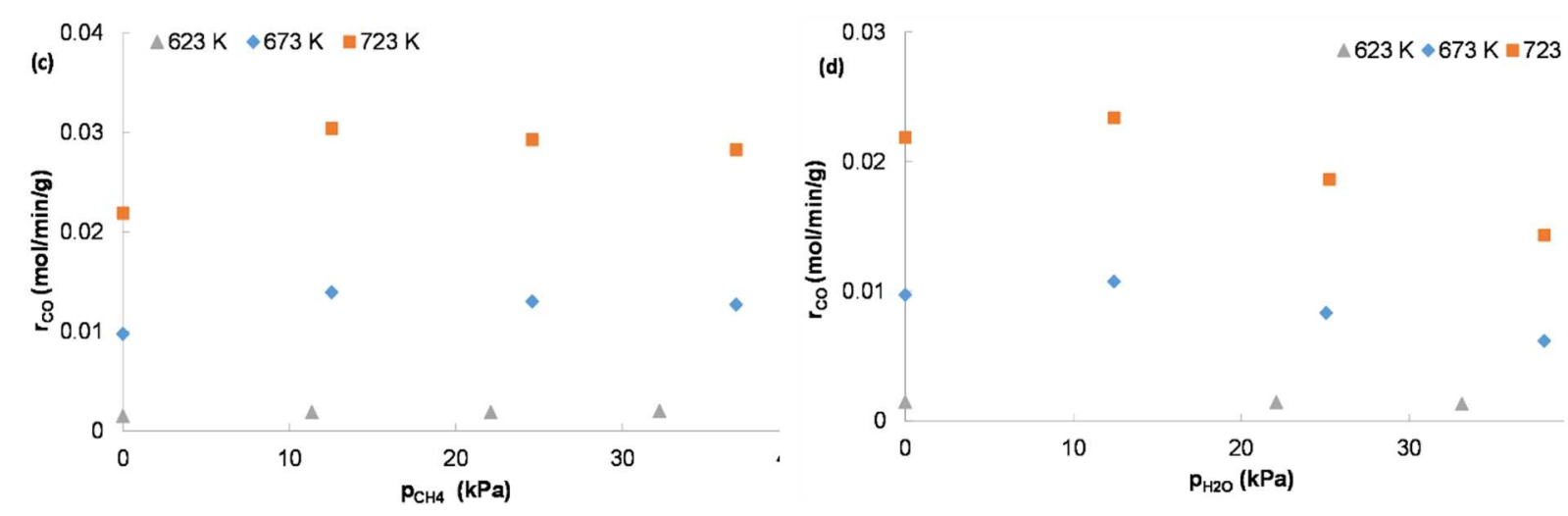

Figure 4 : Effect of partial pressure on RWGS on $1.5 \mathrm{mg} \mathrm{Ni} / \mathrm{Al}_{2} \mathrm{O}_{3}$ catalyst diluted in $\mathrm{SiC}, 115 \mathrm{kPa}$ total pressure and $1.0610^{6} \mathrm{~h}^{-1}$ at $623 \mathrm{~K}-130 \mathrm{kPa}$ total pressure and $3.1610^{6} \mathrm{~h}^{-1}$ at $673 \mathrm{~K}$ and $723 \mathrm{~K}:$ (a) $\mathrm{H}_{2}$ at $22 \mathrm{kPa}^{\mathrm{CO}} \mathrm{CO}_{2}$ partial pressure; (b) $\mathrm{CO}_{2}$ at $55 \mathrm{kPa} \mathrm{H}$ partial pressure; (c) $\mathrm{CH}_{4}$ and (d) $\mathrm{H}_{2} \mathrm{O}$ at $55 \mathrm{kPa} \mathrm{H}$ partial pressure and 22 $\mathrm{kPa} \mathrm{CO} 2$ partial pressure

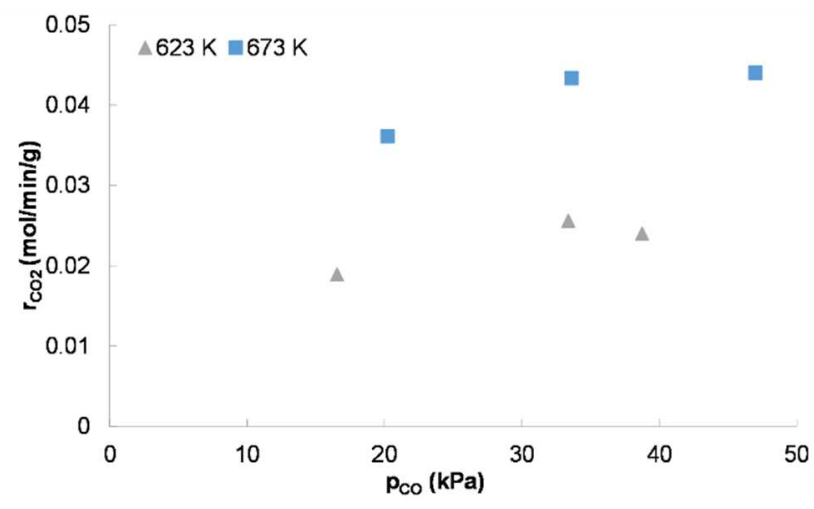

Figure 5 : CO partial pressure dependence on WGS on $1.5 \mathrm{mg} \mathrm{Ni} / \mathrm{Al}_{2} \mathrm{O}_{3}$ catalyst diluted in $\mathrm{SiC}, 20 \mathrm{kPa} \mathrm{H}_{2} \mathrm{O}$ partial pressure, $115 \mathrm{kPa}$ total pressure and $1.0610^{6} \mathrm{~h}^{-1}$ at $623 \mathrm{~K}-140 \mathrm{kPa}$ total pressure and $3.1610^{6} \mathrm{~h}^{-1}$ at $673 \mathrm{~K}$
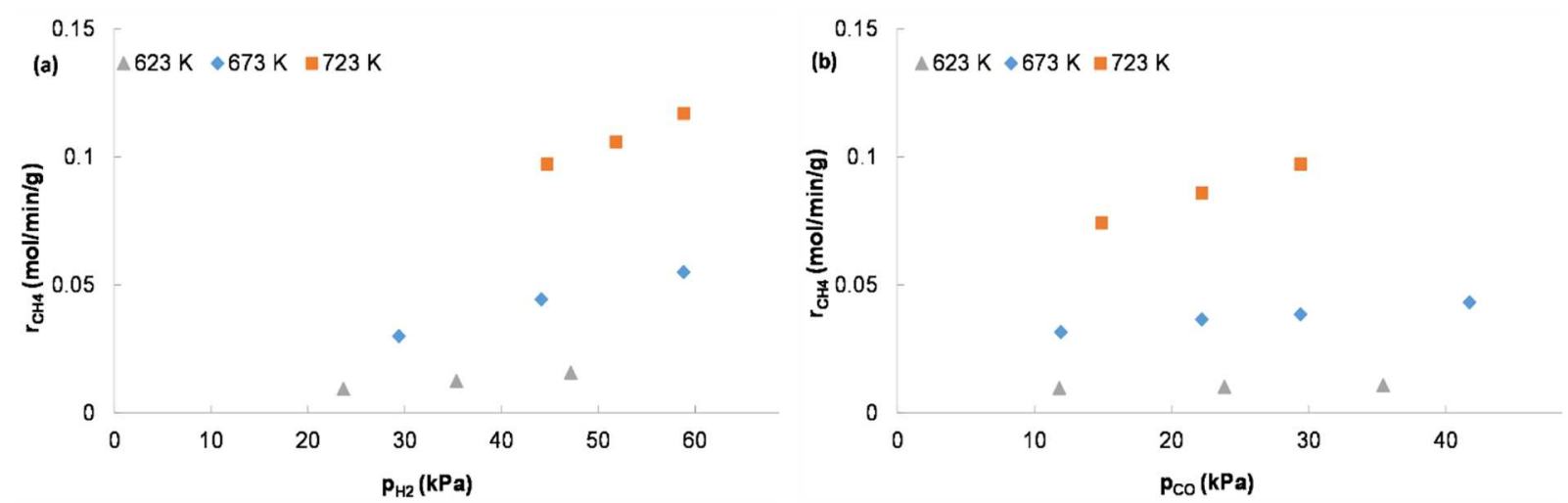

Figure 6 : (a) $\mathrm{H}_{2}$ partial pressure dependence at $25 \mathrm{kPa} \mathrm{CO}$ partial pressure, and (b) $\mathrm{CO}$ partial pressure dependence at $40 \mathrm{kPa} \mathrm{H}$ partial pressure on $\mathrm{CO}$ methanation on $1.5 \mathrm{mg} \mathrm{Ni} / \mathrm{Al}_{2} \mathrm{O}_{3}$ catalyst diluted in $\mathrm{SiC}, 118 \mathrm{kPa}$ total pressure and $1.6610^{6} \mathrm{~h}^{-1}$ at $623 \mathrm{~K}-148 \mathrm{kPa}$ total pressure and $5.010^{6} \mathrm{~h}^{-1}$ at $673 \mathrm{~K}$ and $723 \mathrm{~K}$

\section{Discussion}

The main rate expressions for $\mathrm{CO}_{2}$ methanation, $\mathrm{CO}$ methanation and RWGS commonly used in literature are listed in Table 1. Simplification of these kinetic models in different situations presented below are tested and compared with experimental results obtained at low conversion (below 20\%).

Table 1 : Literature rate expressions for $\mathrm{CO}_{2}$ methanation, $\mathrm{CO}$ methanation and RWGS (including reverse reaction) 


\begin{tabular}{|c|c|c|}
\hline \multicolumn{3}{|c|}{$\mathrm{CO}_{2}$ methanation rate equations } \\
\hline $\begin{array}{l}\text { Xu and } \\
\text { Froment [13] }\end{array}$ & $r_{\mathrm{CO}_{2} \text { meth }}=\frac{k_{\mathrm{CO}_{2} \text { meth }} p_{\mathrm{H}_{2}}^{0.5} p_{\mathrm{CO}_{2}}\left(1-\frac{p_{\mathrm{H}_{2} \mathrm{O}}^{2} P_{\mathrm{CH}_{4}}}{p_{\mathrm{H}_{2}}^{4} p_{\mathrm{CO}_{2}} K_{e q, \mathrm{CO}} \text { meth }}\right)}{\left(1+K_{\mathrm{CO}} p_{\mathrm{CO}}+K_{\mathrm{H}_{2}} p_{\mathrm{H}_{2}}+K_{\mathrm{CH}_{4}} p_{\mathrm{CH}_{4}}+K_{\mathrm{H}_{2} \mathrm{O}} \frac{p_{\mathrm{H}_{2} \mathrm{O}}}{p_{\mathrm{H}_{2}}}\right)^{2}}$ & (5) \\
\hline $\begin{array}{l}\text { Bartholomew } \\
\text { [15] }\end{array}$ & 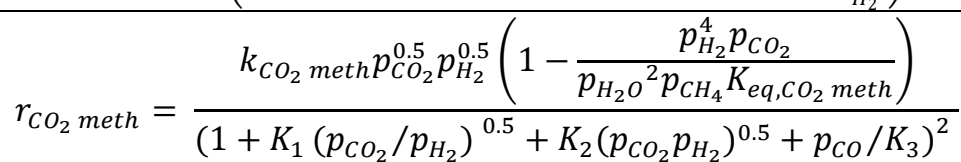 & (6) \\
\hline \multicolumn{3}{|c|}{ RWGS rate equations } \\
\hline $\begin{array}{l}\text { Xu and } \\
\text { Froment [13] }\end{array}$ & $r_{R W G S}=\frac{k_{R W G S} p_{C_{2}}\left(1-\frac{p_{H_{2} O} p_{C O}}{p_{H_{2}} p_{C O_{2}} K_{e q, R W G S}}\right)}{\left(1+K_{C O} p_{C O}+K_{H_{2}} p_{H_{2}}+K_{C H_{4}} p_{C H_{4}}+K_{H_{2} O} \frac{p_{H_{2} O}}{p_{H_{2}}}\right)^{2}}$ & (7) \\
\hline Wheeler [25] & $r_{R W G S}=\frac{k_{R W G S} K_{\mathrm{H}_{2}} K_{\mathrm{CO}_{2}} p_{\mathrm{H}_{2}} p_{\mathrm{CO}_{2}}\left(1-\frac{p_{\mathrm{H}_{2} \mathrm{O}} p_{\mathrm{CO}}}{p_{\mathrm{H}_{2}} p_{\mathrm{CO}_{2}} K_{e q, \mathrm{RWGS}}}\right)}{\left(1+K_{\mathrm{CO}} p_{C O}+K_{\mathrm{H}_{2} \mathrm{O}} p_{\mathrm{H}_{2} \mathrm{O}}+K_{\mathrm{CO}_{2}} p_{\mathrm{CO}_{2}}+K_{\mathrm{H}_{2}} p_{\mathrm{H}_{2}}\right)^{2}}$ & (8) \\
\hline \multicolumn{3}{|c|}{ CO methanation rate equations } \\
\hline $\begin{array}{l}\text { Xu and } \\
\text { Froment [13] }\end{array}$ & 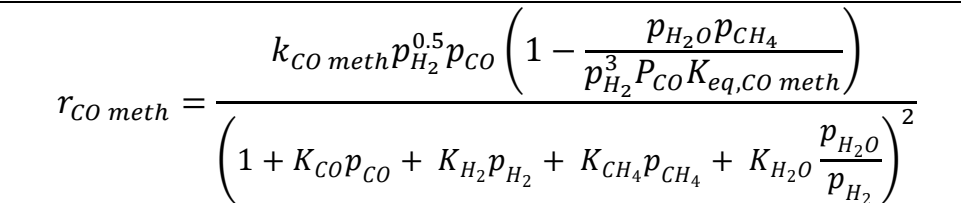 & (9) \\
\hline
\end{tabular}

4.1. $\quad \mathrm{CO}_{2}$ methanation rate equation

The $\mathrm{Xu}$ and Froment kinetic model [13] simplifies as follows at low conversion with a $\mathrm{CO}_{2} / \mathrm{H}_{2}$ feed (as $p_{C O}, p_{\mathrm{CH}_{4}}$, and $p_{\mathrm{H}_{2} \mathrm{O}}$ are negligible):

$$
r_{\text {meth } \mathrm{CO}_{2}}=\frac{k_{\mathrm{CO}_{2} \text { meth }} p_{\mathrm{CO}_{2}} p_{\mathrm{H}_{2}}^{0.5}}{\left(1+K_{\mathrm{H}_{2}} p_{\mathrm{H}_{2}}\right)^{2}}
$$

However, the proportionality between the $\mathrm{CO}_{2}$ methanation reaction rate and the $\mathrm{CO}_{2}$ partial pressure is not obtained experimentally (Figure 7). This model is therefore rejected.

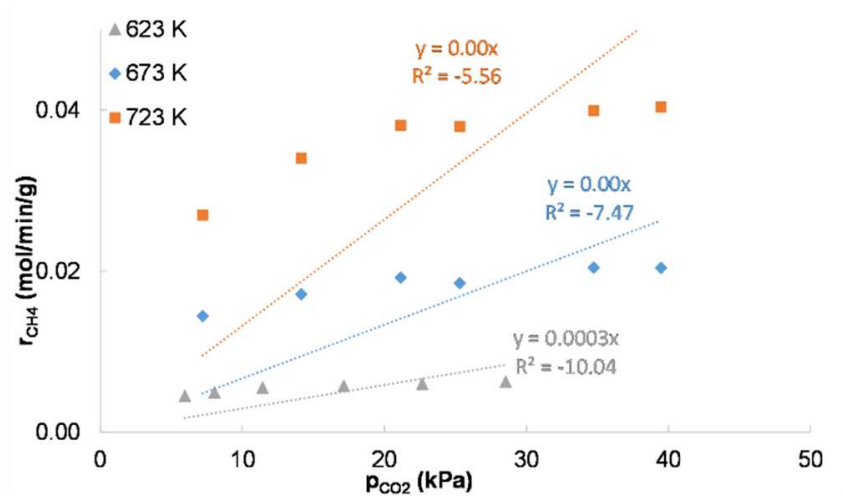

Figure $7: \mathrm{Xu}$ and Froment linear model of the $\mathrm{CO}_{2}$ methanation (lines) according to $p_{\mathrm{CO}_{2}}$ vs experimental data (points) at $623 \mathrm{~K}, 673 \mathrm{~K}$ and $723 \mathrm{~K}$ (low conversion) 
The model proposed by Weatherbee and Bartholomew [15] was also tested. The same method of simplification was applied at low conversion and led to the following expression with a $\mathrm{CO}_{2} / \mathrm{H}_{2}$ feed:

$$
r_{\mathrm{CO}_{2} \text { meth }}=\frac{k_{\mathrm{CO}_{2} \text { meth }} p_{C O_{2}}^{0.5} p_{\mathrm{H}_{2}}^{3 / 2}}{\left(p_{\mathrm{H}_{2}}^{0.5}+K_{1} p_{C O_{2}}^{0.5}+K_{2} p_{\mathrm{H}_{2}} p_{C O_{2}}^{0.5}\right)^{2}}
$$

The validity of this model is verified by linearization of (11). In Figure 8 (a) at $55 \mathrm{kPa} \mathrm{H} 2$ partial pressure, straight lines are obtained as a function of $\left(p_{\mathrm{CO}_{2}}\right)^{0.5}$ while plotting $\left(p_{\mathrm{CO}_{2}}^{0.25} / r_{\mathrm{CO}_{2}}^{0.5}\right.$ meth $)$ at $623 \mathrm{~K}, 673 \mathrm{~K}$ and $723 \mathrm{~K}$. However, in Figure 8 (b) at $22 \mathrm{kPa} \mathrm{CO}$ partial pressure, plots of $\left(p_{\mathrm{H}_{2}}^{0.75} / r_{\mathrm{CO}_{2} \text { meth }}^{0.5}\right)$ with $\left(p_{\mathrm{H}_{2}}\right)^{0.5}$ admit negative coefficients. This would implies that some adsorption or kinetic constants are negative which is not consistent and leads to the rejection of this model.
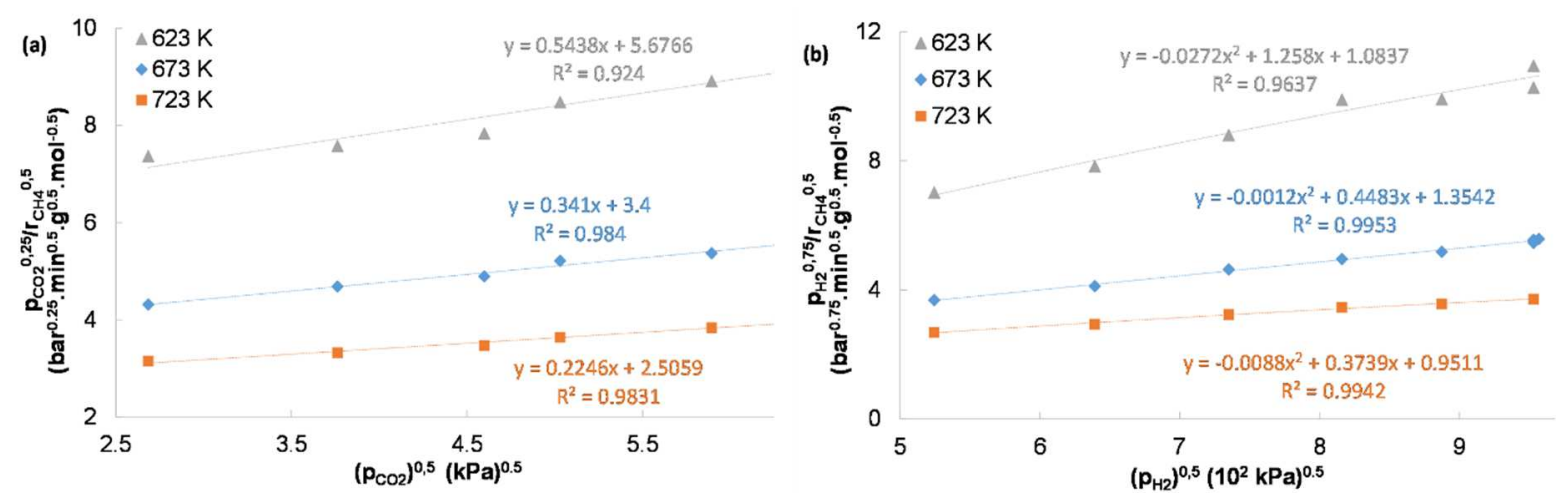

Figure 8 : Bartholomew linear function (a) according to $p_{\mathrm{CO}_{2}}$ and (b) according to $p_{\mathrm{H}_{2}}$ at low $\mathrm{CO}_{2}$ methanation conversion

The simple kinetic model proposed by Wheeler et al. (Eq.(8)) and identified for the WGS reaction [25] is adapted for the $\mathrm{CO}_{2}$ methanation reaction. In the case of $\mathrm{COO}_{2} / \mathrm{H}_{2}$ feed, at low $\mathrm{CO}_{2}$ conversion, the equation becomes:

$$
r_{C O_{2} \text { meth }}=\frac{k_{\mathrm{CO}_{2} \text { meth }} K_{\mathrm{H}_{2}} K_{\mathrm{CO}_{2}} p_{\mathrm{H}_{2}} p_{\mathrm{CO}_{2}}}{\left(1+K_{\mathrm{CO}_{2}} p_{\mathrm{CO}_{2}}+K_{\mathrm{H}_{2}} p_{\mathrm{H}_{2}}\right)^{2}}
$$

Linearization of the kinetics leads to plot $\left(p_{\mathrm{CO}_{2}} / r_{\mathrm{CO}_{2} \text { meth }}\right)^{0.5}$ as a function of $p_{\mathrm{CO}_{2}}$ at constant $p_{\mathrm{H}_{2}}$ and $\left(p_{\mathrm{H}_{2}} / r_{\mathrm{CO}_{2} \text { meth }}\right)^{0.5}$ as a function of $p_{\mathrm{H}_{2}}$ at constant $p_{\mathrm{CO}_{2}}$. A good fit of the experimental results for linear functions are obtained in both Figure 9 (a) at $55 \mathrm{kPa} \mathrm{H}$ partial pressure and (b) at $22 \mathrm{kPa} \mathrm{CO}_{2}$ partial pressure at $623 \mathrm{~K}, 673 \mathrm{~K}$ and $723 \mathrm{~K}$. The mechanism behind this equation assumes a bimolecular limiting step: $\mathrm{CO}_{2} \mathrm{X}+\mathrm{H}_{2} \mathrm{X} \rightarrow \mathrm{COX}+\mathrm{H}_{2} \mathrm{OX}$, where $\mathrm{X}$ is a vacant site on the metal surface [25]. $\mathrm{Th}_{2} \mathrm{H}_{2}$ and $\mathrm{CO}_{2}$ adsorption constants, and the $\mathrm{CO}_{2}$ methanation kinetic constant are identified from the slope and intercept of the regression lines of Figure 9 (a) and (b). The identified constants model correctly the $\mathrm{CH}_{4}$ formation rate at the three temperatures (Figure 10 (a) and (b)).

The inhibition by water (Figure $3(\mathrm{~d})$ ) is accounted for by adding in the adsorption term the $\mathrm{H}_{2} \mathrm{O}$ partial pressure modulated by an adsorption constant, meaning an adsorption competition on the available active sites. The reaction rate expression at low conversion for a $\mathrm{CO}_{2} / \mathrm{H}_{2} / \mathrm{H}_{2} \mathrm{O}$ feed is thus the following:

$$
r_{\mathrm{CO}_{2} \text { meth }}=\frac{k_{\mathrm{CO}_{2} \text { meth }} K_{\mathrm{H}_{2}} K_{\mathrm{CO}_{2}} p_{\mathrm{H}_{2}} p_{\mathrm{CO}_{2}}}{\left(1+K_{\mathrm{CO}_{2}} p_{\mathrm{CO}_{2}}+K_{\mathrm{H}_{2}} p_{\mathrm{H}_{2}}+K_{\mathrm{H}_{2} \mathrm{O}} p_{\mathrm{H}_{2} \mathrm{O}}\right)^{2}}
$$

$\mathrm{H}_{2} \mathrm{O}$ adsorption constant is identified at $623 \mathrm{~K}, 673 \mathrm{~K}$ and $723 \mathrm{~K}$ on the experimental data of Figure 3 (d). The $\mathrm{H}_{2} \mathrm{O}$ inhibition model fits well the $\mathrm{CH}_{4}$ formation rate data (Figure 10 (c)). 

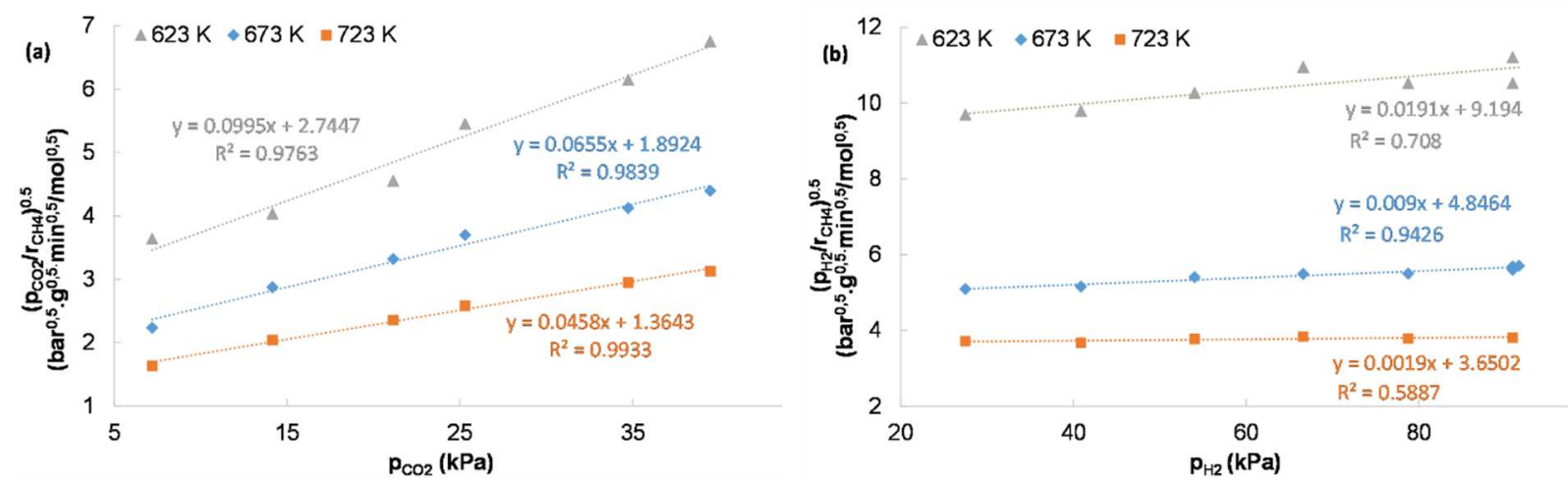

Figure 9 : Plot of the adapted Wheeler linear function $\left(p_{i} / r_{\text {meth } \mathrm{CO}_{2}}\right)^{0.5}$ versus $p_{i}$ at low $\mathrm{CO}_{2}$ methanation conversion (a) $\mathrm{i}=\mathrm{CO}_{2}$ at $55 \mathrm{kPa} \mathrm{H}$ partial pressure and (b) $\mathrm{i}=\mathrm{H}_{2}$ at $22 \mathrm{kPa} \mathrm{CO}_{2}$ partial pressure
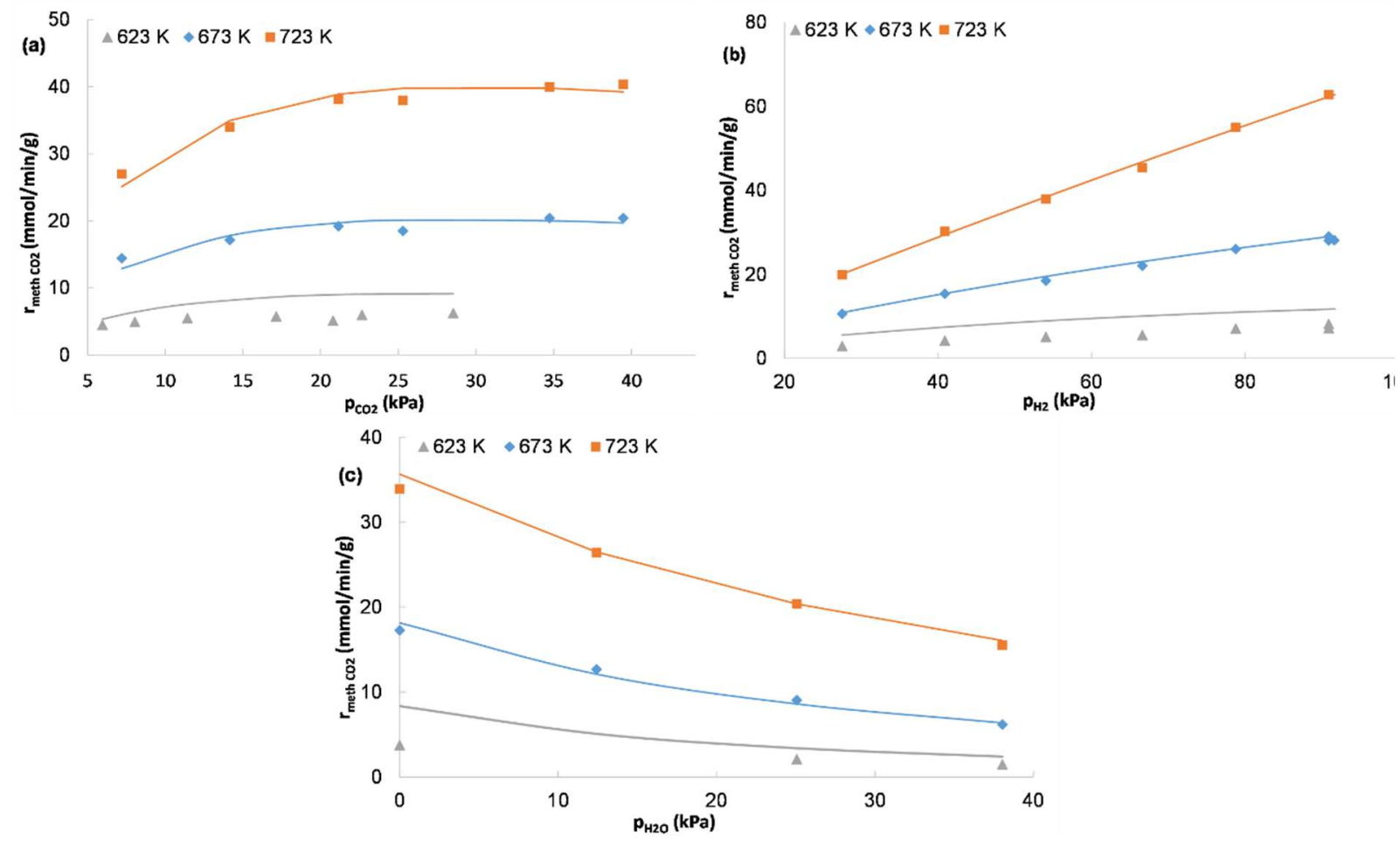

Figure 10 : Comparison between the $\mathrm{CH}_{4}$ formation rate experimental results (points) and the $\mathrm{CO}_{2}$ methanation rate equation predicted by the adapted Wheeler model at low conversion (continuous line) at $623 \mathrm{~K}, 673 \mathrm{~K}$ and $723 \mathrm{~K}$ : (a) Effect of $\mathrm{CO}_{2}$ partial pressure at $55 \mathrm{kPa} \mathrm{H}$ partial pressure, (b) Effect of $\mathrm{H}_{2}$ partial pressure at $22 \mathrm{kPa}$ $\mathrm{CO}_{2}$ partial pressure, (c) Effect of $\mathrm{H}_{2} \mathrm{O}$ partial pressure at $55 \mathrm{kPa} \mathrm{H} \mathrm{H}_{2}$ partial pressure and $22 \mathrm{kPa} \mathrm{CO}_{2}$ partial pressure

\subsection{RWGS rate equation}

According to our results, RWGS is not influenced by hydrogen partial pressure (Figure 4 (a)). The following model is proposed at low $\mathrm{CO}_{2}$ conversion with a $\mathrm{CO}_{2} / \mathrm{H}_{2}$ feed assuming $\mathrm{CO}_{2}$ dissociative adsorption as limiting step: $\mathrm{CO}_{2}+\mathrm{X} \rightarrow \mathrm{CO}+\mathrm{OX}[26,27]$ and tested on the $\mathrm{CO}$ formation rate data:

$$
r_{R W G S}=\frac{k_{R W G S} K_{C O_{2}} p_{\mathrm{CO}_{2}}}{\left(1+K_{\mathrm{H}_{2}} p_{\mathrm{H}_{2}}+K_{\mathrm{CO}_{2}} p_{\mathrm{CO}_{2}}\right)}
$$


The validity of this model is verified by linearization of (14). In Figure 11 , at $55 \mathrm{kPa} \mathrm{H}$ partial pressure, straight lines are obtained as a function of $p_{\mathrm{CO}_{2}}$ while plotting $\left(p_{\mathrm{CO}_{2}} / r_{\mathrm{RWGS}}\right)$ at $623 \mathrm{~K}, 673 \mathrm{~K}$ and $723 \mathrm{~K}$.

Keeping the value of adsorption constants previously determined in the $\mathrm{CO}_{2}$ methanation study, the resolution gives the RWGS kinetic constant to model the $\mathrm{CO}$ formation rate at $623 \mathrm{~K}, 673 \mathrm{~K}$ and $723 \mathrm{~K}$ (Figure 12):

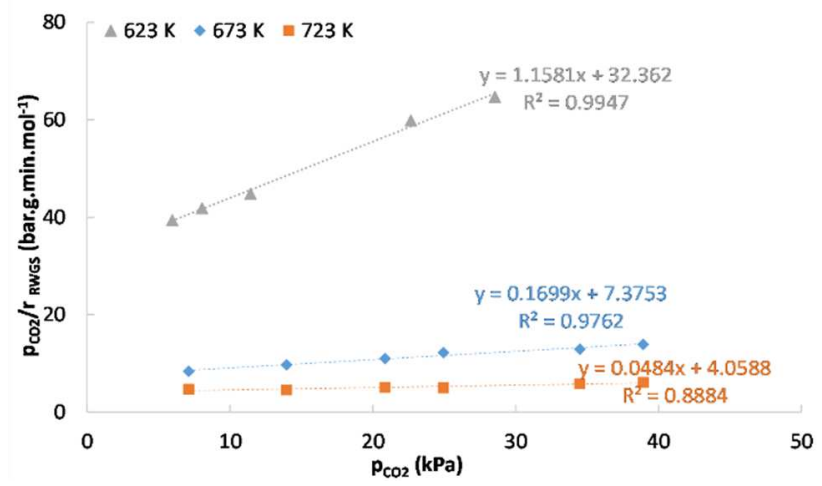

Figure 11: Plot of the proposed RWGS linear model $p_{\mathrm{CO}_{2}} / r_{\text {meth }} \mathrm{CO}_{2}$ versus $p_{\mathrm{CO}_{2}}$ at low $\mathrm{CO}_{2}$ conversion and $55 \mathrm{kPa}$ $\mathrm{H}_{2}$ partial pressure
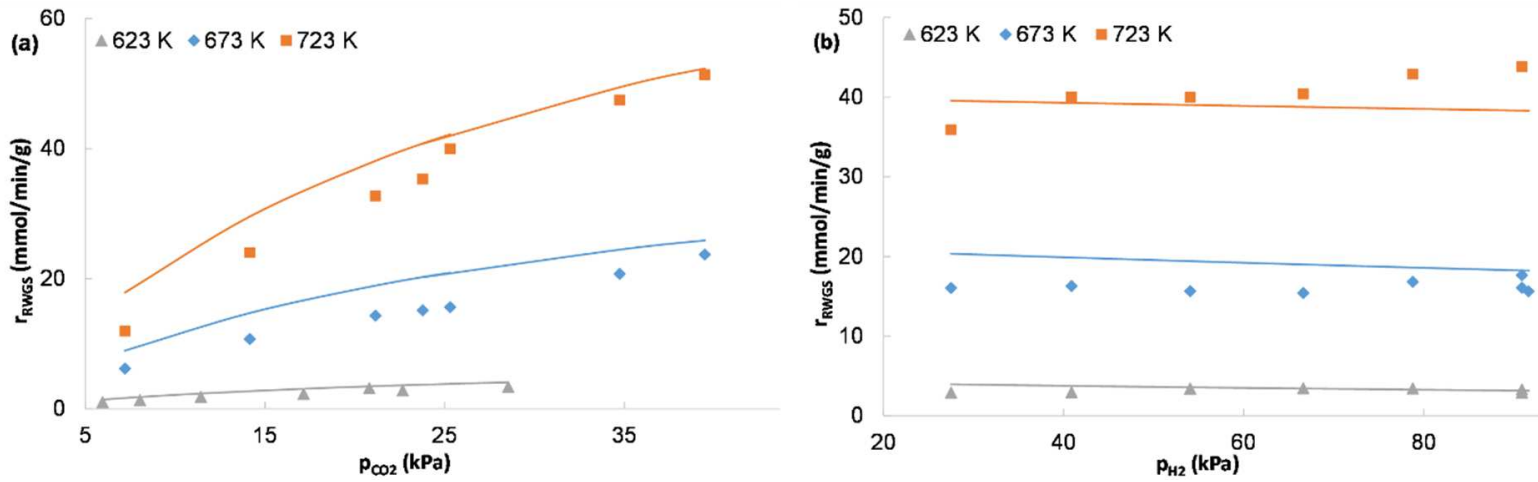

Figure 12 : Comparison between the CO formation rate experimental results (points) and the RWGS rate equation predicted by the adapted model at low conversion (continuous line) at $623 \mathrm{~K}, 673 \mathrm{~K}$ and $723 \mathrm{~K}:$ (a) Effect of $\mathrm{CO}_{2}$ partial pressure at $55 \mathrm{kPa} \mathrm{H} 2$ partial pressure and (b) Effect of $\mathrm{H}_{2}$ partial pressure at $22 \mathrm{kPa} \mathrm{CO}_{2}$ partial pressure

\section{3. $\mathrm{CO}$ methanation rate equation}

Linearization of the $\mathrm{Xu}$ and Froment kinetics at low conversion with a $\mathrm{CO} / \mathrm{H}_{2}$ feed leads to plot $\left(p_{C O}^{0.25} / r_{C O}^{0.5}{ }_{\text {meth }}\right)$ as a function of $p_{\mathrm{H}_{2}}$ at constant $p_{C O}$. However, results are not presented here because negative coefficients are obtained.

Based on the results of the $\mathrm{CO}_{2}$ methanation kinetic study (Eq (12)), the following model is proposed in the case of a low conversion $\mathrm{CO}$ methanation reaction with a $\mathrm{CO} / \mathrm{H}_{2}$ feed:

$$
r_{C O \text { meth }}=\frac{k_{\text {CO meth }} K_{\mathrm{H}_{2}} K_{C O} p_{\mathrm{H}_{2}} p_{C O}}{\left(1+K_{\mathrm{H}_{2}} p_{\mathrm{H}_{2}}+K_{C O} p_{C O}\right)^{2}}
$$

Linearization of the kinetics leads to plot $\left(p_{\mathrm{CO}} / r_{\mathrm{CO} \text { meth }}\right)^{0.5}$ as a function of $p_{\mathrm{CO}}$ at constant $p_{\mathrm{H}_{2}}$ and $\left(p_{\mathrm{H}_{2}} / r_{\mathrm{CO} \text { meth }}\right)^{0.5}$ as a function of $p_{\mathrm{H}_{2}}$ at constant $p_{\mathrm{CO}}$. A good fit of the experimental results for linear functions are obtained in both Figure 13 (a) at $40 \mathrm{kPa} \mathrm{H}_{2}$ partial pressure and (b) at $25 \mathrm{kPa}$ CO partial pressure at $623 \mathrm{~K}, 673 \mathrm{~K}$ and $723 \mathrm{~K}$. The $\mathrm{CO}$ methanation kinetic constant as well as the $\mathrm{CO}$ adsorption constant are identified from the slope and intercept of the regression lines of Figure 13 (a) and (b) knowing the $\mathrm{H}_{2}$ adsorption constant from the $\mathrm{CO}_{2}$ methanation rate equation study. The identified model fits adequately the $\mathrm{CH}_{4}$ formation rate data (Figure 14 (a) and (b)). 

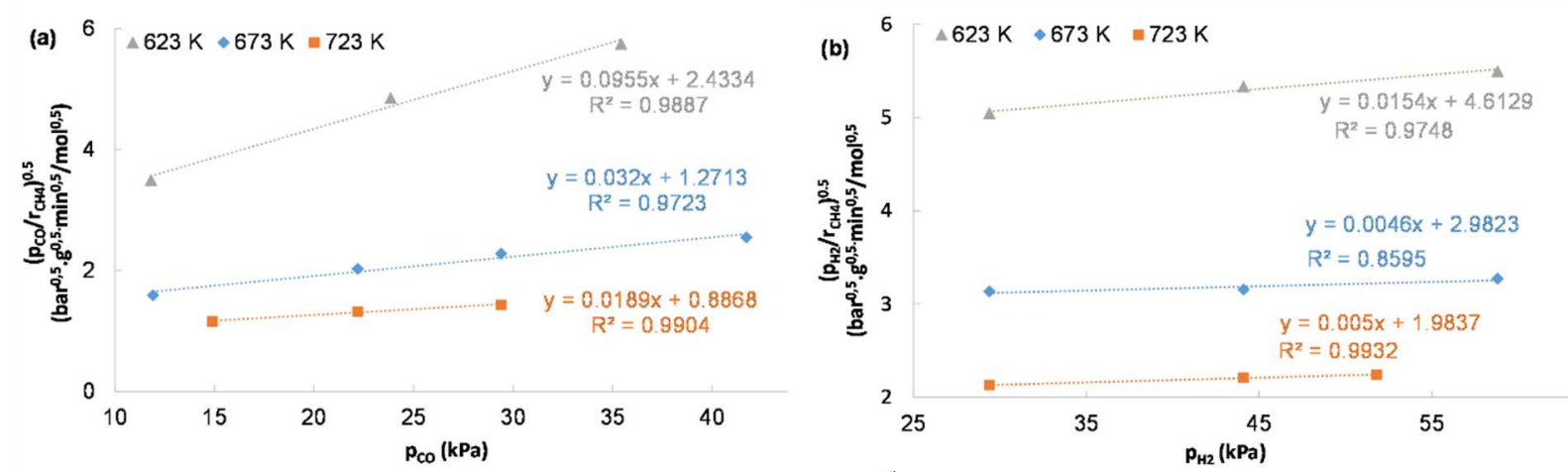

Figure 13: Plot of the adapted linear function $\left(p_{i} / r_{\text {meth }}{ }\right)^{0.5}$ versus $p_{i}$ at low CO methanation conversion (a) $\mathrm{i}=\mathrm{CO}$ at $40 \mathrm{kPa} \mathrm{H}$ partial pressure; (b) $\mathrm{i}=\mathrm{H}_{2}$ at $25 \mathrm{kPa} \mathrm{CO}_{2}$ partial pressure
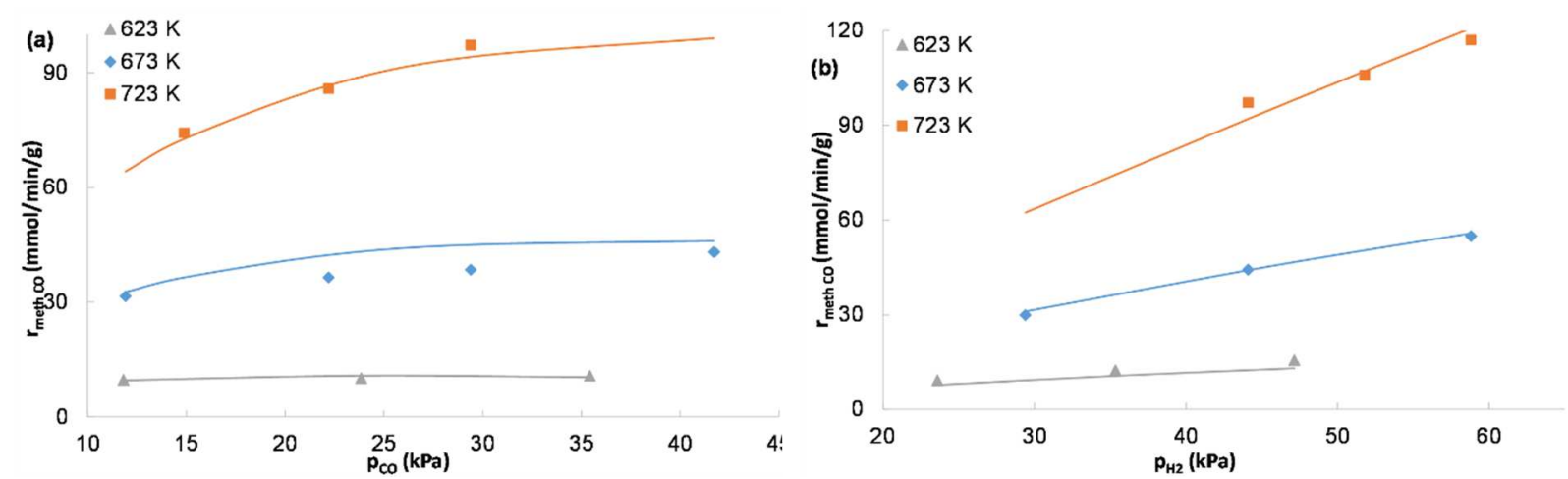

Figure 14 : Comparison between the $\mathrm{CH}_{4}$ formation rate experimental results (points) and the $\mathrm{CO}$ methanation rate equation predicted by the adapted model at low conversion (continuous line) at $623 \mathrm{~K}, 673 \mathrm{~K}$ and $723 \mathrm{~K}$ : (a) Effect of $\mathrm{CO}$ partial pressure at $40 \mathrm{kPa} \mathrm{H}$ partial pressure and (b) Effect of $\mathrm{H}_{2}$ partial pressure at $25 \mathrm{kPa} \mathrm{CO}_{2}$ partial pressure

\section{4. $\quad$ Parameters adjustment}

The kinetic experiments performed at low conversion (below $20 \%$ for all reactive components) allowed to determine the form of the three reaction rates (Eqs (1), (2) and (3)) as well as a first identification of the kinetic and adsorption parameters. The thermodynamic limitations were added to the kinetics established at low conversion in order to consider the global reaction rate of the balanced reaction:

$$
r_{\text {global }}=r^{+}-r^{-}=r^{+}\left(1-\frac{Q_{r}}{K_{e q}}\right)
$$

Moreover, the adsorption of all species likely to compete significantly on the catalyst active sites (i.e. $\mathrm{H}_{2}, \mathrm{CO}_{2}, \mathrm{H}_{2} \mathrm{O}$, and $\mathrm{CO}$ ) was taken into account. The obtained equations are given in Table 2.

Table 2 : Kinetic model of this study

\section{$\mathrm{CO}_{2}$ methanation rate equations}

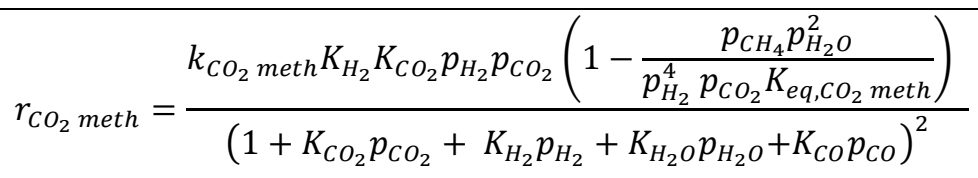

\section{RWGS rate equations}

$$
r_{R W G S}=\frac{k_{R W G S} K_{C O_{2}} p_{C O_{2}}\left(1-\frac{p_{C O} p_{\mathrm{H}_{2} \mathrm{O}}}{p_{\mathrm{H}_{2}} p_{\mathrm{CO}_{2}} K_{e q, R W G S}}\right)}{\left(1+K_{\mathrm{CO}_{2}} p_{\mathrm{CO}_{2}}+K_{\mathrm{H}_{2}} p_{\mathrm{H}_{2}}+K_{\mathrm{H}_{2} \mathrm{O}} p_{\mathrm{H}_{2} \mathrm{O}}+K_{C O} p_{C O}\right)}
$$




$$
r_{\text {CO meth }}=\frac{k_{\text {CO meth }} K_{\mathrm{H}_{2}} K_{C O} p_{\mathrm{H}_{2}} p_{\mathrm{CO}}\left(1-\frac{p_{\mathrm{CH}_{4}} p_{\mathrm{H}_{2} \mathrm{O}}}{p_{\mathrm{H}_{2}}^{3} p_{\mathrm{CO}} K_{e q, \mathrm{CO} \text { meth }}}\right)}{\left(1+K_{\mathrm{CO}_{2}} p_{\mathrm{CO}_{2}}+K_{\mathrm{H}_{2}} p_{\mathrm{H}_{2}}+K_{\mathrm{H}_{2} \mathrm{O}} p_{\mathrm{H}_{2} \mathrm{O}}+K_{\mathrm{CO}} p_{\mathrm{CO}}\right)^{2}}
$$

For a separated set of experiments (described in 2.4), an isothermal plug flow model was used to integrate the three reactions occurring in parallel. As the three reaction rates include three kinetic constants and four adsorption constants, a total of 14 parameters are involved in the rate equations. The adjustments were first performed on the kinetic constants and the adsorption constants at $673 \mathrm{~K}$. This allowed to first reduce the number of parameters from 14 to 7 while keeping a physical meaning when adjusting parameters.

Experimental and theoretical $\mathrm{CO}_{2}$ conversion and $\mathrm{CH}_{4}$ and $\mathrm{CO}$ selectivities are plotted as a function of an equivalent mass of catalyst defined by:

$$
\text { equivalent mass }=\text { real mass } \frac{\text { reference flow rate }}{\text { real flow rate }}
$$

A reference flow rate, being arbitrary fixed at $100 \mathrm{ml}$ (STP) $\mathrm{min}^{-1}$, is used to link the experimental results (with different mass and flow rates) to the modeled values.

First, reaction rates expressions were simplified by introducing apparent kinetic constants as follows:

$$
\begin{gathered}
k_{\text {app,CO}} \text { meth } \\
=k_{\text {app }, \mathrm{RWGS}}=k_{\mathrm{mWGS}} K_{\mathrm{CO}_{2}} \\
\mathrm{CO}_{2} K_{\mathrm{H}_{2}} \\
k_{\text {app,CO meth }}=k_{\mathrm{CO} \text { meth }} K_{C O} K_{\mathrm{H}_{2}}
\end{gathered}
$$

The aim of this mathematical operation is to avoid the influence of adsorption parameters on both numerator and denominator.

With a $\mathrm{H}_{2} / \mathrm{CO}_{2}$ feed, the $\mathrm{CO}_{2}$ methanation and the RWGS are both primary reactions whereas the $\mathrm{CO}$ methanation is a secondary reaction. Hence, for each temperature, the ratio between $\mathrm{CH}_{4}$ and $\mathrm{CO}$ selectivities extrapolated at equivalent mass of zero corresponds to the ratio of $\mathrm{CO}_{2}$ methanation over RWGS initial rates. The obtained ratio allowed to link kinetic constants of $\mathrm{CO}_{2}$ methanation to RWGS reaction. The number of parameters is thus declined to 6 .

As conversion at relatively low equivalent mass is not sensitive to secondary reaction, conversion was then adjusted by tuning RWGS kinetic constant (and so $\mathrm{CO}_{2}$ methanation automatically with).

Furthermore, the kinetic constant of the $\mathrm{CO}$ methanation was adjusted by adjusting $\mathrm{CO}$ selectivities in the whole range of equivalent mass.

The adsorption constants were then modified in the denominator of the rate equations to fit the form of the curve of $\mathrm{CO}_{2}$ conversion and $\mathrm{CH}_{4}$ and $\mathrm{CO}$ selectivities (i.e. inhibit more or less the reaction rates). Based on the roughly estimated parameters, the influence of the $\mathrm{CO}$ adsorption constant on the reaction rates is much weaker than the ones of the three other compounds involved $\left(\mathrm{CO}_{2}, \mathrm{H}_{2}\right.$ and $\left.\mathrm{H}_{2} \mathrm{O}\right)$, this parameter was thus not changed.

Once the adsorption parameters modified, the sequence was repeated iteratively until good fits were obtained at a given temperature. The procedure was then repeated for the 2 other temperatures with the constraint of acceptable Arrhenius plots for each of the 7 kinetic and adsorption constants.

Comparison of the experimental and theoretical $\mathrm{CO}_{2}$ conversions and $\mathrm{CH}_{4}$ and $\mathrm{CO}$ selectivities at 623 , 673 and $723 \mathrm{~K}$ are presented in Figure 15 for the adjusted parameters. As the obtained error is small at the three temperatures, the adjusted apparent kinetic constants allowed to calculate real kinetic constants present in Eqs (16), (17) and (18). 
The final parameters given in Table 3 predict with an accuracy of $20 \%$ the $\mathrm{CH}_{4}$ formation rate (Figure 16) for the three temperatures and conversion rates ranging from $5 \%$ to $75 \%$.
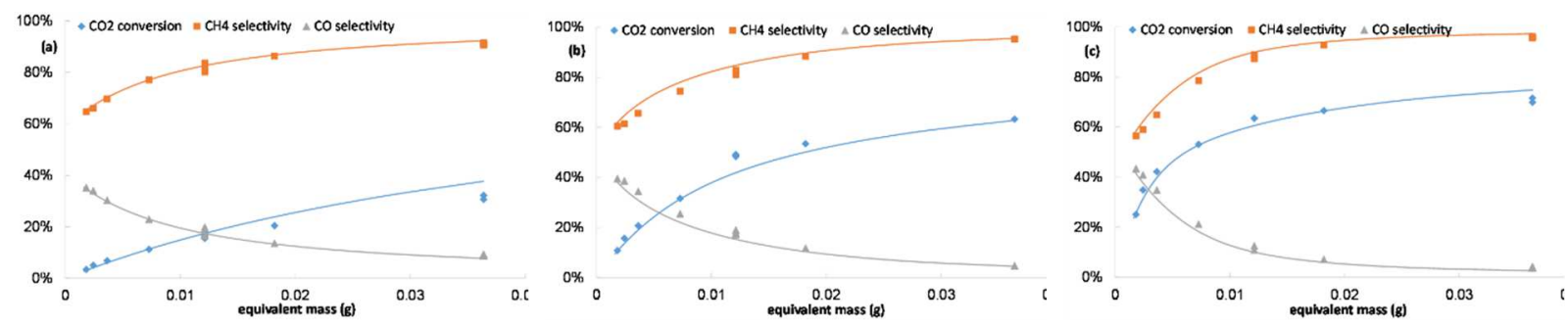

Figure 15: $\mathrm{CO}_{2}$ conversion and $\mathrm{CH}_{4}$ and $\mathrm{CO}$ selectivities of an isothermal plug flow reactor for a molar ratio $\mathrm{H}_{2} / \mathrm{CO}_{2} / \mathrm{N}_{2}=74 / 17 / 9$ - continuous line: model - point: experimental value: (a) at $623 \mathrm{~K}$; (b) at $673 \mathrm{~K}$ and (c) at 723 $\mathrm{K}$

Table 3 : Final parameters of the kinetic model following an Arrhenius law for the kinetic constants and as Van't Hoff type for the adsorption constants

\begin{tabular}{|c|c|c|c|c|c|}
\hline \multirow{3}{*}{$\begin{array}{l}\text { Adsorption } \\
\text { constants }\end{array}$} & & Kco & $\mathrm{K}_{\mathrm{H} 2 \mathrm{O}}$ & $\mathrm{KcO} 2$ & $\mathrm{~K}_{\mathrm{H} 2}$ \\
\hline & $\mathrm{Q}\left(\mathrm{kJ} \mathrm{mol}^{-1}\right)$ & 40.6 & 14.5 & 9.72 & 52.0 \\
\hline & $\mathrm{K}_{0}\left(\mathrm{bar}^{-1}\right)$ & $2.3910^{-3}$ & $6.0910^{-1}$ & 1.07 & $5.2010^{-5}$ \\
\hline \multirow{3}{*}{$\begin{array}{l}\text { Kinetic } \\
\text { constants }\end{array}$} & & $k_{\mathrm{CO}_{2} \text { meth }}$ & $k_{R W G S}$ & $k_{\text {Co meth }}$ & \\
\hline & $\mathrm{Ea}\left(\mathrm{kJ} \mathrm{mol}^{-1}\right)$ & 110 & 97.1 & 97.3 & \\
\hline & $\mathrm{k}_{0}\left(\mathrm{~mol} \mathrm{~min}^{-1} \mathrm{~g}^{-1}\right)$ & $1.1410^{8}$ & $1.7810^{6}$ & $2.2310^{8}$ & \\
\hline
\end{tabular}

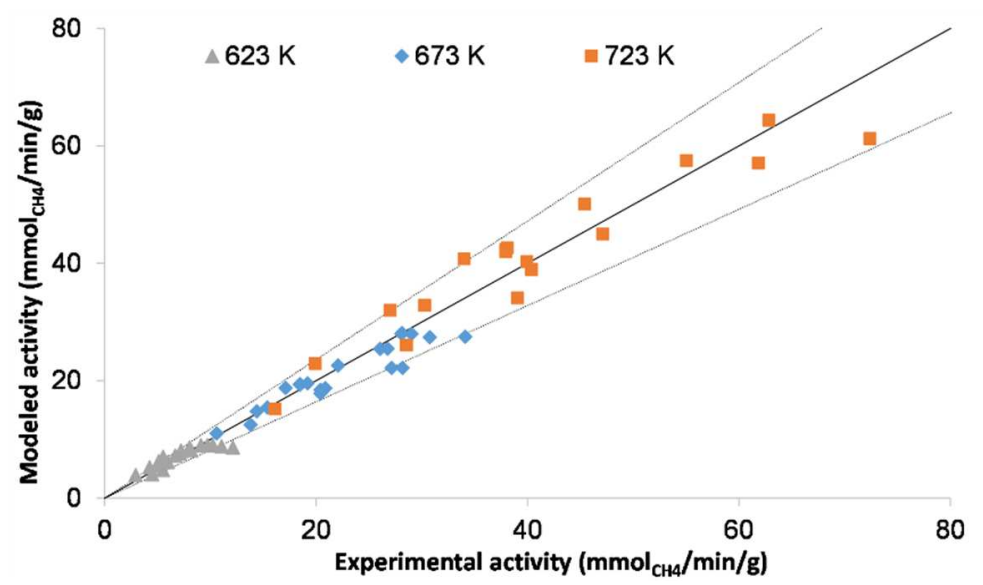

Figure 16: Parity plot of the experimental and modeled $\mathrm{CH}_{4}$ activity within $20 \%$ error at $623 \mathrm{~K}, 673 \mathrm{~K}$ and $723 \mathrm{~K}$ $\mathrm{H}_{2} / \mathrm{CO}_{2} / \mathrm{N}_{2}$ at the reactor inlet (data taken from experiments at low conversion and parameters adjustment experiments)

\section{Conclusion}

An intrinsic kinetic model was proposed to represent both the direct and indirect paths of the $\mathrm{CO}_{2}$ methanation reaction (i.e. $\mathrm{CO}_{2}$ methanation and Reverse Water Gas Shift + $\mathrm{CO}$ methanation) between $623 \mathrm{~K}$ and $723 \mathrm{~K}$, at atmospheric pressure. 
First, the partial pressure rate dependence of each component was established on each reaction, at different temperatures to select the form of the three kinetic laws and to identify the kinetic and adsorption parameters. For these tests, the $\mathrm{CO}_{2}$ conversion (CO conversion) was limited to $20 \%$ in order to consider only the direct direction of the $\mathrm{CO}_{2}$ methanation and RWGS (CO methanation).

Then, these parameters were adjusted by minimizing the error between the $\mathrm{CO}_{2}$ conversion and $\mathrm{CH}_{4}$ and $\mathrm{CO}$ selectivities predicted by an isothermal plug-flow model and several tests at higher conversion rate at $623 \mathrm{~K}, 673 \mathrm{~K}$ and $723 \mathrm{~K}$. An excellent fit was obtained allowing the prediction of the $\mathrm{CH}_{4}$ formation rate within $20 \%$ error.

Future works will include a kinetic model validation at the $\mathrm{CO}_{2}$ methanation milli-structured fixed-bed reactor-exchanger scale. The final purpose will be the prediction of the catalyst activity over time on stream inside the $\mathrm{CO}_{2}$ methanation reactor using the kinetic model of this study coupled with a deactivation model.

\section{Acknowledgments}

This work was supported by the French Environment and Energy Management Agency (ADEME), French Alternative Energies and Atomic Energy Commission (CEA) and ATMOSTAT. It is the result of experiments conducted at the ICPEES Laboratory in Strasbourg.

\section{Nomenclature}

\begin{tabular}{|c|c|}
\hline$E a$ & Activation energy $\left(\mathrm{J} \mathrm{mol}^{-1}\right)$ \\
\hline$F$ & Molar flow $\left(\mathrm{mol} \mathrm{min}^{-1}\right)$ \\
\hline GHSV & Gas Hourly Space Velocity $\left(h^{-1}\right)$ \\
\hline$k_{j}$ & Reaction rate constant of reaction $\mathrm{j}\left(\mathrm{mol} \mathrm{min}^{-1} \mathrm{~g}^{-1}\right)$ \\
\hline$k_{0}$ & Pre-exponential factor of rate constant $\left(\mathrm{mol} \mathrm{min} \mathrm{m}^{-1} \mathrm{~g}^{-1}\right)$ \\
\hline$K_{i}$ & Adsorption equilibrium constant of constituent $\mathrm{i}\left(\mathrm{bar}^{-1}\right)$ \\
\hline$K_{0}$ & Pre-exponential factor for adsorption equilibrium constant $\left(\mathrm{bar}^{-1}\right)$ \\
\hline$K_{e q, j}$ & Equilibrium constant of reaction $\mathrm{j}$ \\
\hline$p_{i}$ & Partial pressure of constituent $\mathrm{i}$ \\
\hline$Q$ & Heat of adsorption $\left(\mathrm{J} \mathrm{mol}^{-1}\right)$ \\
\hline$Q_{r}$ & Reaction quotient (-) \\
\hline$r_{j}$ & Reaction rate of reaction $\mathrm{j}$ \\
\hline$r_{C_{4}}$ & Reaction rate of methane formation $\left(\mathrm{mol} \mathrm{min}^{-1} \mathrm{~g}^{-1}\right)$ \\
\hline$r_{C O}$ & Reaction rate of $\mathrm{CO}$ formation $\left(\mathrm{mol} \mathrm{min}^{-1} \mathrm{~g}^{-1}\right)$ \\
\hline$r_{\text {global }}$ & Global reaction rate $\left(\mathrm{mol} \mathrm{min}^{-1} \mathrm{~g}^{-1}\right)$ \\
\hline$r^{+}$ & Direct reaction rate $\left(\mathrm{mol} \mathrm{min}^{-1} \mathrm{~g}^{-1}\right)$ \\
\hline$r^{-}$ & Reverse reaction rate ( $\left.\mathrm{mol} \mathrm{min}^{-1} \mathrm{~g}^{-1}\right)$ \\
\hline$R$ & Ideal gas constant $\left(\mathrm{R}=8.314 \mathrm{~J} \mathrm{~mol}^{-1} \mathrm{~K}^{-1}\right)$ \\
\hline$T$ & Temperature $(\mathrm{K})$ \\
\hline \multicolumn{2}{|c|}{ Greek letters } \\
\hline$\Delta_{r} H$ & Heat of reaction $\left(\mathrm{J} \mathrm{mol}^{-1}\right)$ \\
\hline$\Psi$ & Inert dilution factor $\left(\Psi=\mathrm{m}_{\mathrm{Sic}} / m_{\text {catalyst }}\right)$ \\
\hline
\end{tabular}

\section{Appendices}

Supplementary material related to the theoretical heat and mass transfer limitations verifications is available.

\section{References}

[1] M.A.A. Aziz, A.A. Jalil, S. Triwahyono, A. Ahmad, $\mathrm{CO}_{2}$ methanation over heterogeneous catalysts: recent progress and future prospects, Green Chem. 17 (2015) 2647-2663. doi:10.1039/C5GC00119F. 
[2] P. Frontera, A. Macario, M. Ferraro, P. Antonucci, Supported Catalysts for $\mathrm{CO}_{2}$ Methanation: A Review, Catalysts. 7 (2017) 59. doi:10.3390/catal7020059.

[3] J. Gao, Q. Liu, F. Gu, B. Liu, Z. Zhong, F. Su, Recent advances in methanation catalysts for the production of synthetic natural gas, RSC Adv. 5 (2015) 22759-22776. doi:10.1039/C4RA16114A.

[4] M. Götz, J. Lefebvre, F. Mörs, A. McDaniel Koch, F. Graf, S. Bajohr, R. Reimert, T. Kolb, Renewable Power-to-Gas: A technological and economic review, Renew. Energy. 85 (2016) 1371-1390. doi:10.1016/j.renene.2015.07.066.

[5] Y. Li, S.H. Chan, Q. Sun, Heterogeneous catalytic conversion of $\mathrm{CO}_{2}$ : a comprehensive theoretical review, Nanoscale. 7 (2015) 8663-8683. doi:10.1039/C5NR00092K.

[6] S. Rönsch, J. Schneider, S. Matthischke, M. Schlüter, M. Götz, J. Lefebvre, P. Prabhakaran, S. Bajohr, Review on methanation - From fundamentals to current projects, Fuel. 166 (2016) 276296. doi:10.1016/j.fuel.2015.10.111.

[7] W. Wang, S. Wang, X. Ma, J. Gong, Recent advances in catalytic hydrogenation of carbon dioxide, Chem. Soc. Rev. 40 (2011) 3703. doi:10.1039/c1cs15008a.

[8] J. Sabatier, P. Senderens, Nouvelles synthèses de méthane, Compt Rend. (1902) 514-516.

[9] J. Gao, Y. Wang, Y. Ping, D. Hu, G. Xu, F. Gu, F. Su, A thermodynamic analysis of methanation reactions of carbon oxides for the production of synthetic natural gas, RSC Adv. 2 (2012) 2358. doi:10.1039/c2ra00632d.

[10] P.J. Lunde, F.L. Kester, Carbon dioxide methanation on a ruthenium catalyst, Ind. Eng. Chem. Process Des. Dev. 13 (1974) 27-33.

[11] J.H. Chiang, J.R. Hopper, Kinetics of the hydrogenation of carbon dioxide over supported nickel, Ind. Eng. Chem. Prod. Res. Dev. 22 (1983) 225-228.

[12] R.E. Hayes, W.J. Thomas, K.E. Hayes, A study of the nickel-catalyzed methanation reaction, J. Catal. 92 (1985) 312-326.

[13] J. Xu, G.F. Froment, Methane steam reforming, methanation and water-gas shift: I. Intrinsic kinetics, AIChE J. 35 (1989) 88-96.

[14] J. Ducamp, A. Bengaouer, P. Baurens, Modelling and experimental validation of a $\mathrm{CO}_{2}$ methanation annular cooled fixed-bed reactor exchanger, Can. J. Chem. Eng. 95 (2017) 241-252. doi:10.1002/cjce.22706.

[15] G.D. Weatherbee, C.H. Bartholomew, Hydrogenation of $\mathrm{CO}_{2}$ on group VIII metals: II. Kinetics and mechanism of CO2 hydrogenation on nickel, J. Catal. 77 (1982) 460-472.

[16] F. Koschany, D. Schlereth, O. Hinrichsen, On the kinetics of the methanation of carbon dioxide on coprecipitated $\mathrm{NiAl}(\mathrm{O}) \mathrm{x}$, Appl. Catal. B Environ. $181 \quad$ (2016) 504-516. doi:10.1016/j.apcatb.2015.07.026.

[17] C.V. Miguel, A. Mendes, L.M. Madeira, Intrinsic kinetics of $\mathrm{CO}_{2}$ methanation over an industrial nickel-based catalyst, J. CO2 Util. 25 (2018) 128-136. doi:10.1016/j.jcou.2018.03.011.

[18] A. Bengaouer, J. Ducamp, I. Champon, R. Try, Performance evaluation of fixed-bed, millistructured, and metallic foam reactor channels for $\mathrm{CO}_{2}$ methanation, Can. J. Chem. Eng. 96 (2018) 1937-1945. doi:10.1002/cjce.23140.

[19] S. Danaci, L. Protasova, J. Lefevere, L. Bedel, R. Guilet, P. Marty, Efficient $\mathrm{CO}_{2}$ methanation over $\mathrm{Ni} / \mathrm{Al}_{2} \mathrm{O}_{3}$ coated structured catalysts, Catal. Today. 273 (2016) 234-243. doi:10.1016/j.cattod.2016.04.019.

[20] D. Schlereth, O. Hinrichsen, A fixed-bed reactor modeling study on the methanation of $\mathrm{CO}_{2}$, Chem. Eng. Res. Des. 92 (2014) 702-712. doi:10.1016/j.cherd.2013.11.014.

[21] H. Gierman, Design of laboratory hydrotreating reactors: scaling down of trickle-flow reactors, Appl. Catal. 43 (1988) 277-286.

[22] D.E. Mears, The role of axial dispersion in trickle-flow laboratory reactors, Chem. Eng. Sci. 26 (1971) $1361-1366$.

[23] C.F. Chu, K.M. Ng, Flow in packed tubes with a small tube to particle diameter ratio, AIChE J. 35 (1989) 148-158.

[24] S. Ergun, Fluid Flow through packed columns, Chem. Eng. Prog. 48 (1952) 89-92.

[25] C. Wheeler, The water-gas-shift reaction at short contact times, J. Catal. 223 (2004) 191-199. doi:10.1016/j.jcat.2004.01.002.

[26] M.S. Spencer, On the activation energies of the forward and reverse water-gas shift reaction, Catal. Lett. 32 (1995) 9-13.

[27] E.L. Fornero, D.L. Chiavassa, A.L. Bonivardi, M.A. Baltanás, Transient analysis of the reverse water gas shift reaction on $\mathrm{Cu} / \mathrm{ZrO}_{2}$ and $\mathrm{Ga}_{2} \mathrm{O}_{3} / \mathrm{Cu} / \mathrm{ZrO}_{2}$ catalysts, J. CO2 Util. 22 (2017) 289-298. doi:10.1016/j.jcou.2017.06.002. 


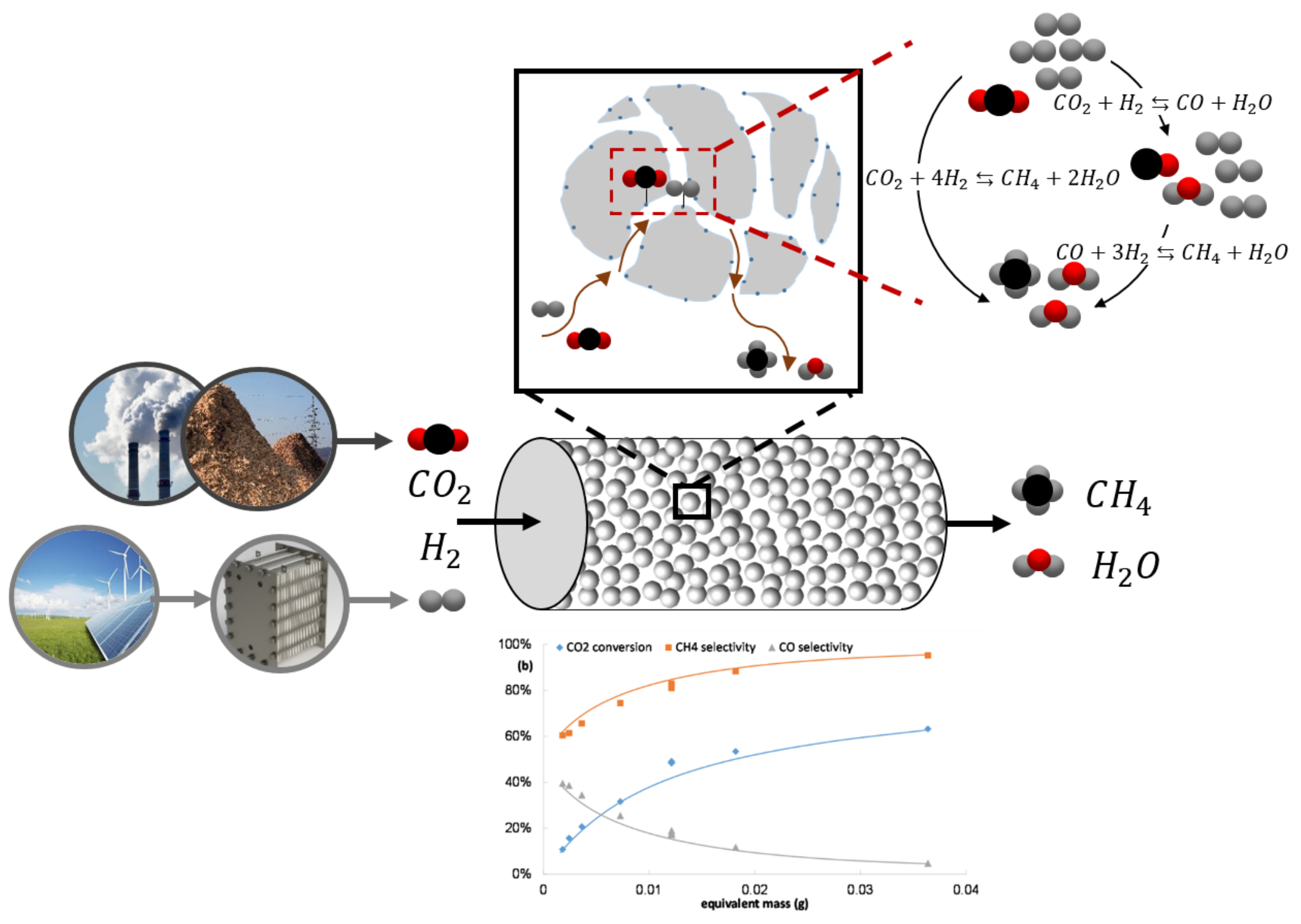

